\title{
Screening and Identification of Potential iNOS Inhibitors to Curtail Cervical Cancer Progression: An in-Silico Drug Repurposing Approach
}

PAVAN KUMAR POLEBOYINA ( $\square$ pavanbiotech2012@gmail.com )

Osmania University Faculty of Science https://orcid.org/0000-0003-0393-3917

\section{SMITA C PAWAR}

Osmania University Faculty of Science

AKBAR PASHA

Osmania University

RAVINDER DONETI

Osmania University

SNEHA MALLESWARI POLEBOYINA

Andhra University

SHIVAJI BANOTHU

Osmania University

Deepthi pasumarthi

Osmania University

\section{Annapurna SD}

Osmania University

Kumbhakar Divya

Osmania University

\section{Research Article}

Keywords: NOS2 (iNOS), Nitric Oxide Synthase, Cervical Cancer, Drug repurposing, FDA approved anticancer drugs, Small Molecules

Posted Date: July 9th, 2021

DOl: https://doi.org/10.21203/rs.3.rs-674491/v1

License: (c) (i) This work is licensed under a Creative Commons Attribution 4.0 International License.

Read Full License 
Version of Record: A version of this preprint was published at Applied Biochemistry and Biotechnology on October 27th, 2021. See the published version at https://doi.org/10.1007/s12010-021-03718-2. 


\title{
Screening and identification of potential iNOS inhibitors to curtail cervical cancer progression: An in-silico drug repurposing approach
}

\author{
Pavan Kumar Poleboyina ${ }^{1}$, Akbar Pasha ${ }^{1}$, Ravinder Doneti ${ }^{1}$, Sneha Malleswari \\ Poleboyina $^{2}$, Shivaji. B ${ }^{1}$, Deepti .P. ${ }^{1}$, Annapurna $S D^{1}$, Divya $K^{1}$, \\ Smita C Pawar ${ }^{1 *}$
}

${ }^{1}$ Department of Genetics \& Biotechnology, University College of Science, Osmania University, Hyderabad-500007, Telangana, India. Email: pavanbiotech2012@ gmail.com

${ }^{2}$ Department of Pharmaceutical Biotechnology, AU College of Pharmaceutical Sciences, Andhra University, Visakhapatnam-530003, Andhra Pradesh, India.

*Corresponding author email address: dr.smitapawar@osmania.ac.in

\begin{abstract}
:
Cervical cancer is the second most common cause of cancer deaths in women worldwide and remains the main reason of mortality amongst women of reproductive age in developing countries. Nitric oxide is involved in several physiological functions inclusive of inflammatory and immune responses. However, the function of NO in tumor biology is debatable. The inducible NOS (iNOS/NOS2) isoform is the one responsible to maintain the levels of NO and it exhibits pleotropic effects in various cancer with concentration-dependent pro- and anti-tumor effects.NOS 2 triggers angiogenesis and endothelial cell migration in tumors by regulating the levels of vascular endothelial growth factor (VEGF). In drug discovery, drug repurposing involves investigations of approved drug candidates to treat various other diseases. In this study, we used FDA-approved anti-cancer drugs and small molecules to target iNOS and identify a potential selective iNOS inhibitor. The structures of ligands were geometrically optimized, and energy minimized using Hyperchem software. Molecular docking was performed using Molegro virtual docker and ligands were selected based on MolDock score, Rerank score, and H-bonding energy. In the study showed 4 compounds, Degarelix, Goserelin, Triptorelin pamoate, and venetoclax demonstrated excellent binding affinity to NOS2 protein. These compounds exhibited the lowest MolDock score, Rerank score, with better H-bonding energy to NOS2. Based on the results theses ligands project to be promising potential NOS2 inhibitors to curtail cervical cancer progression
\end{abstract}

Keywords: NOS2 (iNOS), Nitric Oxide Synthase, Cervical Cancer, Drug repurposing, FDA approved anti-cancer drugs, Small Molecules

\section{INTRODUCTION}


Continual human papillomavirus (HPV) infection is the primary reason for cervical cancer and it has led to the development of prophylactic vaccines to prevent HPV infection and HPV assays.[1]. In World, cervical cancer (CC) ranks second in causing cancer deaths in women. Due to the increased pap smear test for early detection of $\mathrm{CC}$, the average death rate has declined in developed countries[2]. The global prevalence of cervical cancer is about 510,000 new cases annually, with about 288,000 deaths globally[3].In India, 122,844 women get diagnosed and 67,477 succumb to death from the disease of Cervical Cancer annually. In the Indian population, 15 years and older-aged women are at high risk of developing cancer and cervical cancer is the second most common cancer in women aged 15-44years. By comparing the highest standardized incidence of cervical cancer in South Asia, India has the highest age at 22 than other countries i.e. 19.2 in Bangladesh, 13 in Sri Lanka, and 2.8 in Iran.

Nitric Oxide (NO) is one of the principal oxides of nitrogen that mediates a variety of actions such as neurotransmission, host defense, iron metabolism, and vasodilatation but increased NO production contribute to a variety of disorders including cancer[4]. NOS2(iNOS) is a member of a Nitric Oxide Synthase(NOS) family of enzymes and produces NO-[5]. There are three isoforms of NOS in nature: endothelial (eNOS), neural (nNOS), and inducible(iNOS), the inducible NOS exhibits increased expression in several types of cancer but the prognostic role in cervical cancer still remains unclear[6].

In our previous study, we demonstrated that iNOS expression levels were reduced by using plant-derived diterpenoid andrographolide, in both in-silico and in-vitro[7]. In the present study we adopt an Insilco drug repurposing approach to identify a potential inhibitor for NOS2 by using FDA approved anti-cancer drugs and small molecules.

\section{MATERIALS AND METHODS}

The study involves retrieval of target protein in PDB format from RCSB Protein Data Bank[8] and retrieval of ligands, FDA approved anti-cancer drugs and small molecules from Pubchem database[9], Zinc database[10], and Drug bank[11]. Due to the presence of cofactors and peptide bonds in ligands, some structures were drawn and converted into pdb files through Hyperchem8 software[12] and ChemDraw Pro 12.0 software (RRID:SCR_016768)[13]. Molecular Docking was carried out by Molegro Virtual Docker (MVD2019_7_0_0)(RRID:SCR_000190)[14], data analyzed by Molegro Data modeler[15] and results were envisioned by Molegro Molecular Viewer[16].

\section{Retrieval of target protein}

$3 d$ structure of NOS2 (iNOS) Human inducible nitric oxide synthase with inhibitor protein (PDB ID: 4NOS) was retrieved from RCSB Protein Data Bank. Before docking, the unwanted hetero atoms, water molecules, and other ligand compounds were removed by MVD.

\section{Retrieval of FDA approved anti-cancer drugs and small molecules}


1,116 compounds were virtually screened and a total of 162top hit lead optimized compounds were selected for further analysis. The $3 \mathrm{~d}$ and $2 \mathrm{~d}$ structures of ligands were retrieved from Pubchem database zinc database, drug bank, and some structures were drawn in ChemDraw pro 12.0 and Hyperchem 8 package; they were pre-optimized using molecular mechanics force field procedure $\left(\mathrm{MM}^{+}\right.$, AMBER) in Hyperchem8[17]. To get the conformers of FDA-approved anti-cancer drugs and small molecules with the lowest energy, the semi-empirical method AM-1 was applied to the molecular structures. To avoid the local stability, each molecular structure was geometrically optimized several times with different starting points using the Polak-Rebiere algorithm, till the root-mean-square gradient becomes equal to 0.01 and $0.001 \mathrm{kcal}^{-1} \mathrm{~mol}^{-1}[18]$. Finally the energy minimizations of each ligand structure was performed. the first step and second step calculations i.e. single point calculations that are used to determine the total molecular energy of structure and geometric optimization calculations $\left(\mathrm{MM}^{+}, \mathrm{AMBER}\right.$ force field) to determine the energy minimization algorithms that locate the flexible structures were done by using Hyperchem8[19].

\section{Prediction of ligand binding active sites}

The ligand-binding active sites in NOS2 (iNOS, PDB ID: 4NOS) protein for FDAapproved anti-cancer drugs and small molecule ligands are not well characterized. The amino acid residues responsible for active site formation in NOS2 protein were identified through the MVD cavity detection algorithm. This MVD detected 5 different active sites with high volume surface in NOS2 protein.

\section{Protein preparation}

NOS2 human inducible nitric oxide synthase with inhibitor protein (PDB ID: 4NOS) was selected for the molecular docking studies using MVD. All necessary $\mathrm{H}$ atom addition, valency checks were performed. MVD provided utilities and protein preparation i.e. protonation addition of mismatched amino acid residues was repaired, optimized and rebuilt by MVD. For docking studies it is important that the imported structures must be prepared accurately, the atom connectivity and bond orders are correct and the partial atomic charges are assigned. PDB files have a poor or missing assignment of explicit hydrogen's, and the PDB file format cannot accommodate bond order information. Then the repair, rebuilt and optimized protein was saved in *.Mol format. The final structure was visualized and analyzed with SPDBV 4.1.0 (RRID:SCR_013295)[20] wind control panel and BIOVIA Discovery studio (BIOVIA_2021.DS2021Client) software (RRID:SCR_015651)[21].

\section{Ligand preparation}

The selected FDA-approved anti-cancer drugs and small molecules were downloaded from Pubchem, Zinc database, and drug bank. Some torsion and peptide bond containing candidates were drawn and minimized its energy by using Hyperchem8 software and imported to MVD workspace in *.Mol format. Before import, the small molecules and FDA-approved anti-cancer 
drugs are subjected to series of steps to generate optimization and variation of the structure, as the energy minimized ligands have the capability to form better bonding with protein.

\section{Docking studies}

In the current study, a docking algorithm called MolDock has been used. It is based on a new hybrid search algorithm, called guided differential evolution. It combines differential evolutional optimization technique with an active site prediction algorithm[22]. For the docking process GRID resolution was set to $0.30 \AA$, and the cavities were set on the coordinate values $\mathrm{X}=$ 16.90, $\mathrm{Y}=61.22$ and $\mathrm{Z}=17.64$. Other embedded parameters were used which consist of a maximum iteration of 1,500, simplex evolution of 300, Neighbour distance factor 1.00, and the highest population size of 50. For each ligand 10 independent runs were performed with the differential evolution algorithm, with every 10 independent runs of these docking returning 5 docking poses and selecting the top most pose for consideration. MVD shows higher docking accuracy than the other docking software(MVD: 87\%, Glide: 82\%, Surflex: 75\%, FlexX: 58\%)[23]. The scoring function used by MVD is called MolDock which is derived from the PLP scoring functions. The docking scoring function MolDock score energy, $\mathrm{E}_{\text {score }}$ is defined by (1), where $\mathrm{E}_{\text {inter }}$ is the ligandreceptor interaction energy and $\mathrm{E}_{\text {intra }}$ is the internal energy of the ligand. According to (2) equation, $E_{\text {inter }}$ is calculated.

$$
\begin{aligned}
E_{\text {score }} & =E_{\text {inter }}+E_{\text {intra }} \\
E_{\text {inter }} & =\sum_{i=\text { ligand }} \sum_{j=\text { protein }}\left[E_{P L P\left(r_{i j}\right)}+332.0 \frac{q_{i} q_{j}}{4 r_{i j}^{2}}\right]
\end{aligned}
$$

The EPLP is a piecewise linear potential by using two different sets of parameters i.e. the steric and Hydrogen bonds[24]. According to (3) equation $E_{\text {intra }}$ is calculates the energy involves in the pair of atoms of the ligand and torsional energy where $\mathrm{h}$ is the torsional angle of the bond.

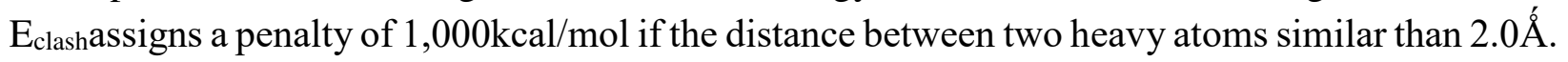

$E_{\text {intra }}=\sum_{i=\text { ligand }} \sum_{j=\text { protein }}\left[E_{P L P}\left(r_{i j}\right)\right]+\sum_{\text {flexible bond }} A\left[1-\cos \left(m \theta-\theta_{\circ}\right)\right]+E_{\text {clash }}$.

\section{Pharmacophore modeling}

By using the LigandScout 4.4.5 software package(RRID:SCR_014889) the structure-based pharmacophore model was generated[25]. Herein the proposed algorithm studies and interprets 
ligand-receptor interactions such as hydrogen bonds, hydrophobic regions, and charge transfer regions of the macromolecular environment from PDB files and allowing the automatic binding of the pharmacophore model. The exclusion volume spheres were added to the generated pharmacophore model which represents the inaccessible areas along with any potential ligand[26].

\section{Drug-likeness and ADMET properties}

The drug scan and ADMET properties were performed to determine the inhibitor has the fulfilled conditions as the drug candidate based on Lipinski's Rule of Five[27]. The pharmacokinetic properties, toxicity, and Bioavailability of selected ligands were carried out by using the Molinspiration chemiinformatics tool[28], SwissADME tool[29], and pkCSM tool[30].

\section{RESULTS}

\section{Target protein structural information}

The NOS2 (iNOS) human inducible nitric oxide synthase protein(PDB ID: 4NOS) with a resolution of $2.25 \AA$ was retrieved from the RCSB protein data bank. The structural confirmations of protein were obtained by PDBsum[31] and obtained PROCHEK[32], ERRAT[33] validations by uploading its structure in structure validation server (SAVESv6.0)[34]. The obtained 3d cartoon, secondary structural analysis, and Ramachandran plot are shown in Fig.1 


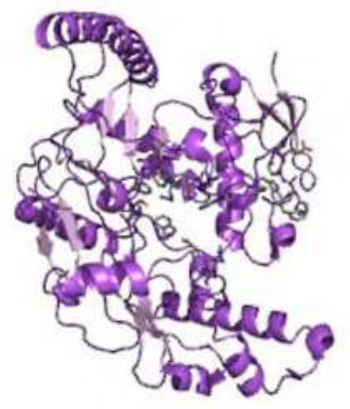

(a)

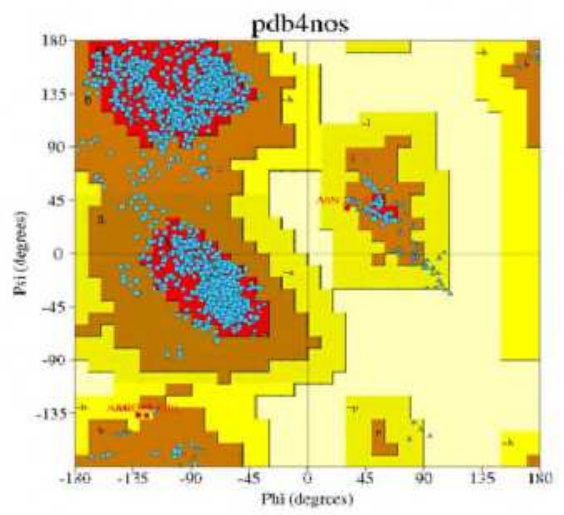

(c)

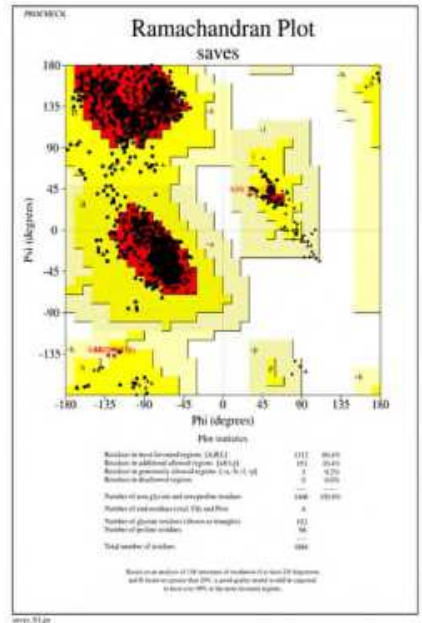

(d)

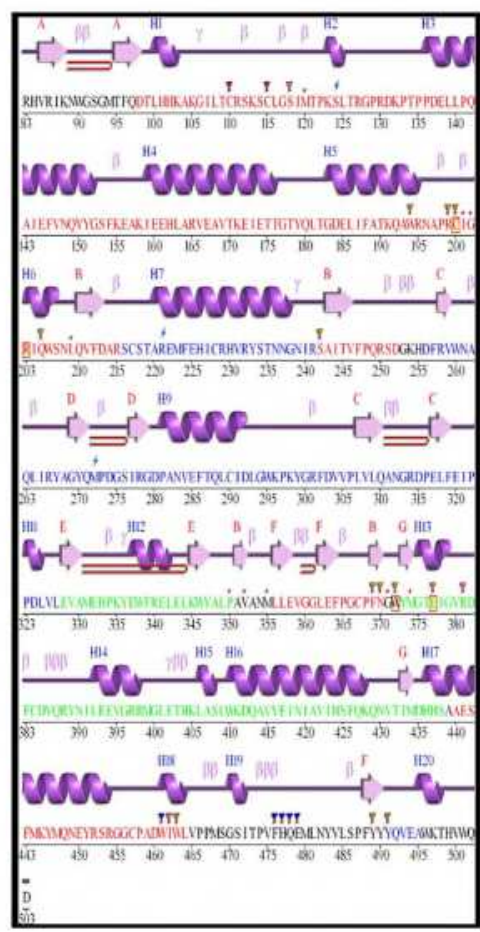

(b)

Fig.1shows structural information of protein NOS2 (a) 3d cartoon structure (b) secondary structure of 3pty mapped obtained using PDBsum (c) and (d) Ramachandran plot

The NOS2 protein active sites were obtained by the MVD cavity detection algorithm the five detected cavities with their volume are illustrated in Fig.2 


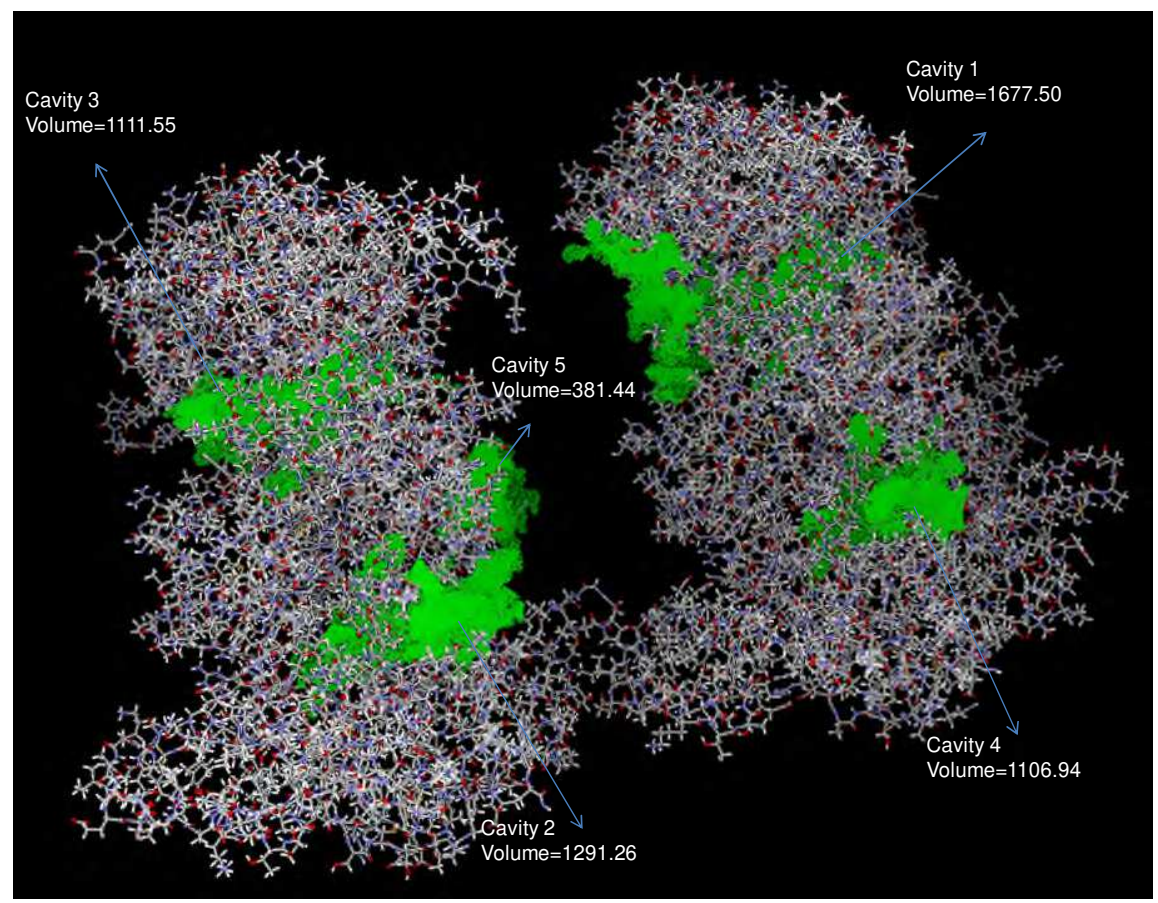

Fig.2 MVD generated cavities of protein NOS2

\section{LIGAND STRUCTURE INFORMATION}

Total 162 ligand structures of FDA-approved anti-cancer drugs and small molecules were used in docking to find out its inhibitory binding effect with the target protein. The drug compounds structural information and its flexibility confirmation with after single point and geometry optimization minimized energies are represented in Table 1

\section{Docking Results validation}

Herein we used MVD for docking studies to obtain MolDock score, Rerank score, Interaction energy, torsions, and H-bonding energy. To find out the protein-ligand interaction each compound undergoes 10runs with threshold energy 100 and is finally given 5 best poses. Out of 5 poses, we have selected the top 1 pose for each ligand having the lower energy along withhigher MolDock score, lower rerank score, and best hydrogen bonding. The obtained energies of each ligand are shown in Table 2

Among all docked 162 ligands, 4 compounds showedharmonious inhibitory effect with NOS2 protein. Based on the average MolDock score $-150 \mathrm{kcal} / \mathrm{mol}$ to $-160 \mathrm{kcal} / \mathrm{mol}$, we have selected above-average MolDock score obtained ligands for further studies. The top 4compounds; Degarelix, Goserelin, Triptorelin pamoate, and Venetoclax revealed the lowest MolDock score on 
NOS2 protein which is $-226.10 \mathrm{kcal} / \mathrm{mol},-189.77 \mathrm{kcal} / \mathrm{mol},-185.73 \mathrm{kcal} / \mathrm{mol}$, and $-168.21 \mathrm{kcal} / \mathrm{mol}$ respectively.

Degarelix binds into the active site of NOS2 protein with MolDock score $-226.10 \mathrm{kcal} / \mathrm{mol}$ and its binding site consist of amino acid residues were Glu394C, Glu393C, Asn390C, Val386C, Glu387C, Glu91D, Pro474D, Ser92D, His477D, Glu441D, Lys445D, Ile204D, Asn449D, Glu448D, Met444D, Met94D, Asn89D, Lys88D, Thr95D, Arg86D. The docked amino acid residues against the ligand were Asn449D, Met94D, Ser92D, Pro474D, Val386C, Asn89D.

Goserelin binds into the active site of NOS2 protein with MolDock score $-189.77 \mathrm{kcal} / \mathrm{mol}$ and its binding site consist of amino acid residues were Val386C, Glu387C, Gly91D, Glu93D, Ser92D, Asu89D, Met94D, Phe96D, Glu448D, Met447D, Lys445D, Met444D, Glu478D, Pro474D, Gly441D. The docked amino acid residues against the ligand were Glu441D, Gly91D, Met444D, Ser92D.

Triptorelin pamoate binds into the active site of iNOS protein with MolDock score $185.73 \mathrm{kcal} / \mathrm{mol}$ and its binding site consist of amino acid residues were Pro474D, Val386C, Glu441D, Lys445D, Met444D, Arg452D, Asn449D, Glu448D, Phe96D, Met94D, Gly478D, Asn89D, Ser92D. The docked amino acid residues against the ligand were Glu448D, Met444D,Ser92D.

Venetoclax binds into the active site of iNOS protein with MolDock score $-168.21 \mathrm{kcal} / \mathrm{mol}$ and its binding site consist of amino acid residues were Gly93D,Met94D,Asn89D,Ser92D,Glu448D,Lys445D,Met444D,Pro474D,Glu441D. The docked amino acid residues against the ligand were Ser92D, Glu448D.Fig.3 illustrates the top 4 ligands hydrogen bonding interactions with amino acid residues of NOS2 protein. 


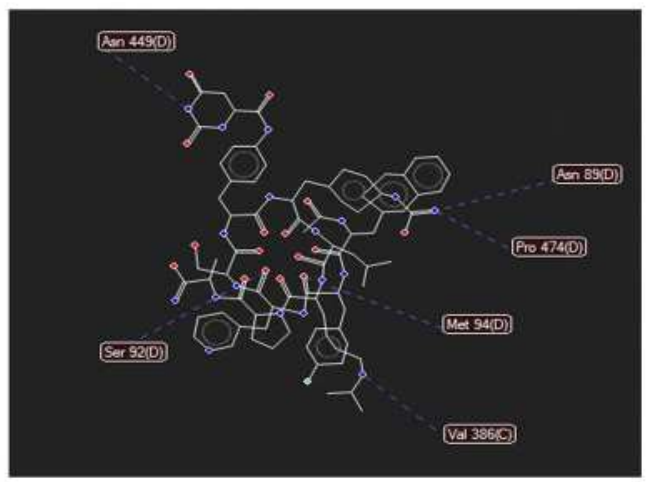

(a)

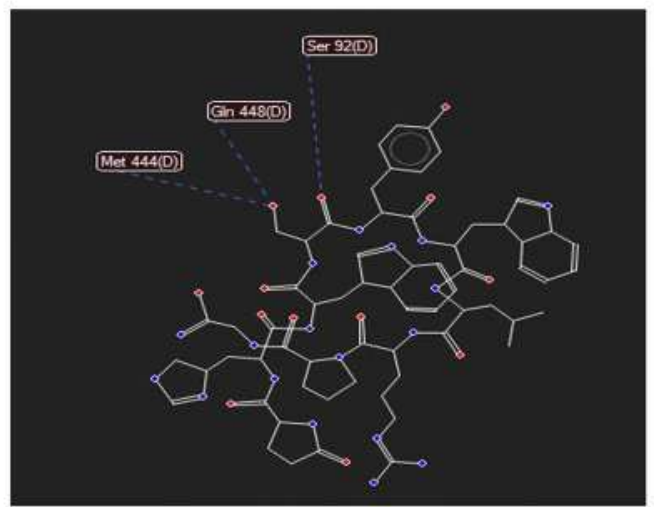

(c)

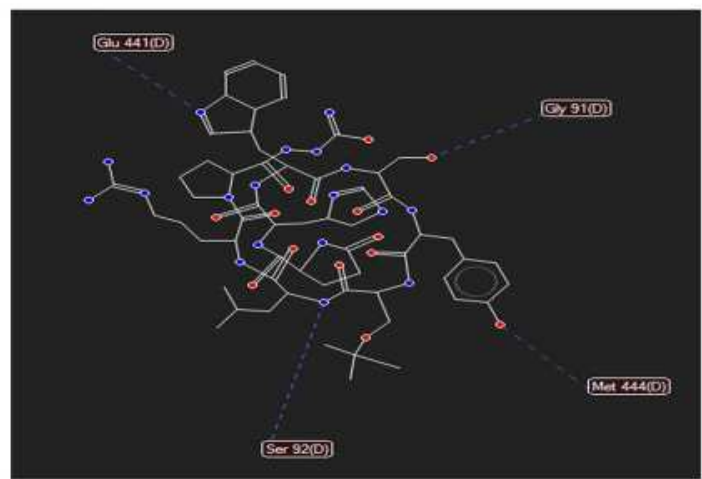

(b)

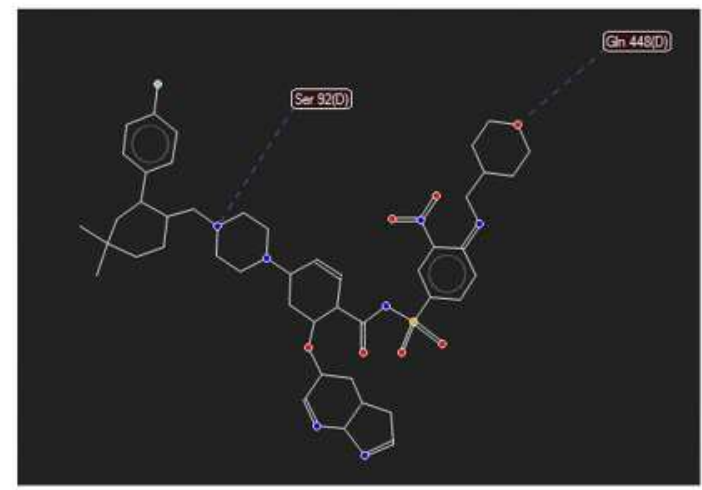

(d)

Fig.3: Hydrogen bond interactions of ligands with protein NOS2 (a) Degarelix (b) Goserelin (c)Triptorelin pamoate (d) Venetoclax

Fig.4 represents the key amino acid residues of NOS2 protein which forming steric interactions with ligands. Fig.5 and Fig. 6 show the ligand docked against the crystal protein structures of human inducible nitric oxide synthase and the amino acid residues around active \& docked against NOS2 protein respectively (Table 3). Our validated results of pharmacophore models are illustrated in Fig.7 


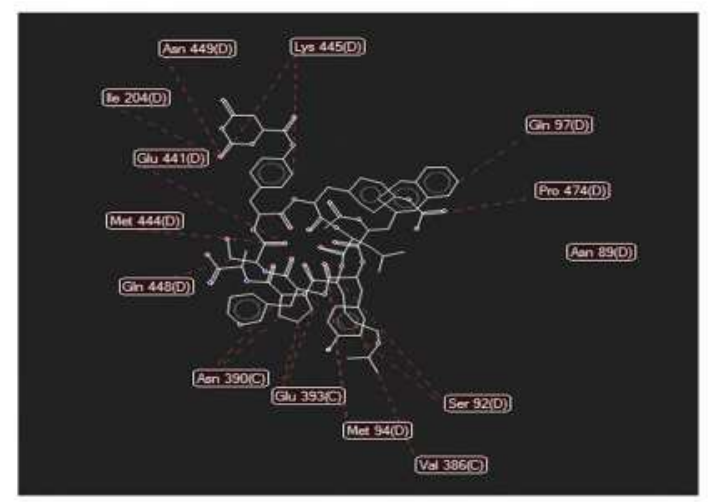

(a)

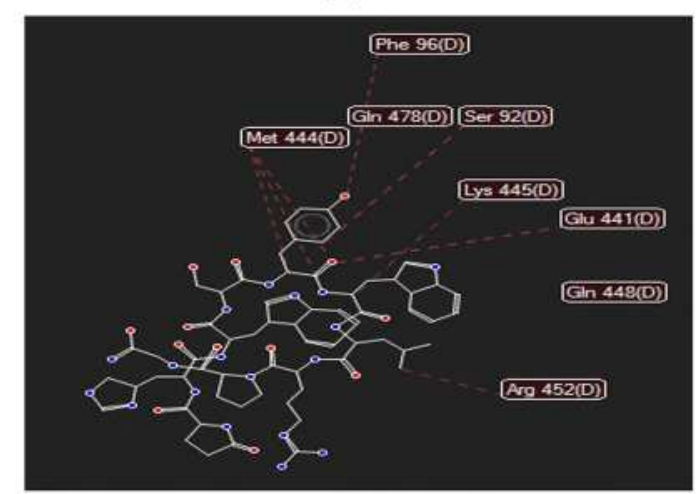

(c)

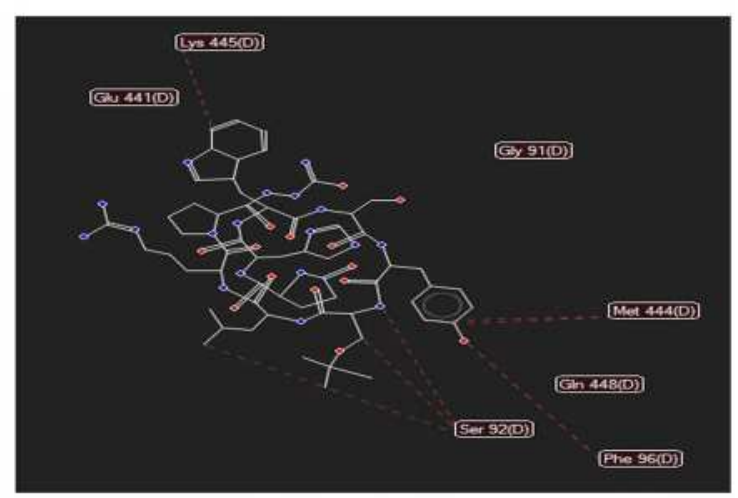

(b)

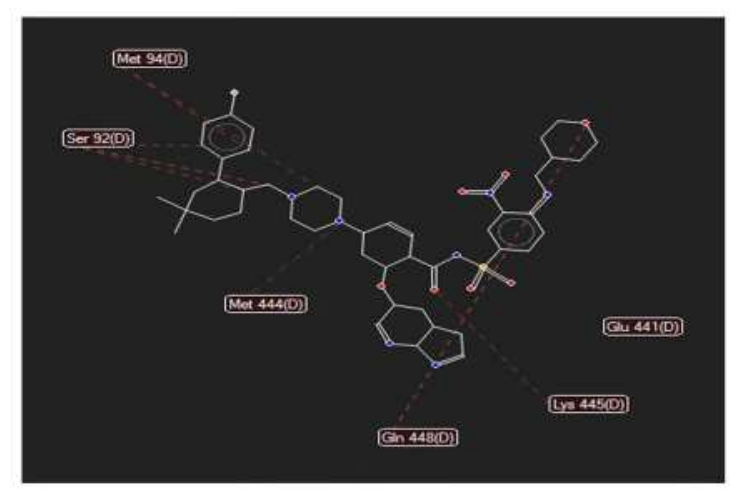

(d)

Fig.4Steric interactions of ligands with NOS2 protein (a) Degarelix (b) Goserelin (c) Triptorelin pamoate (d) Venetoclax 


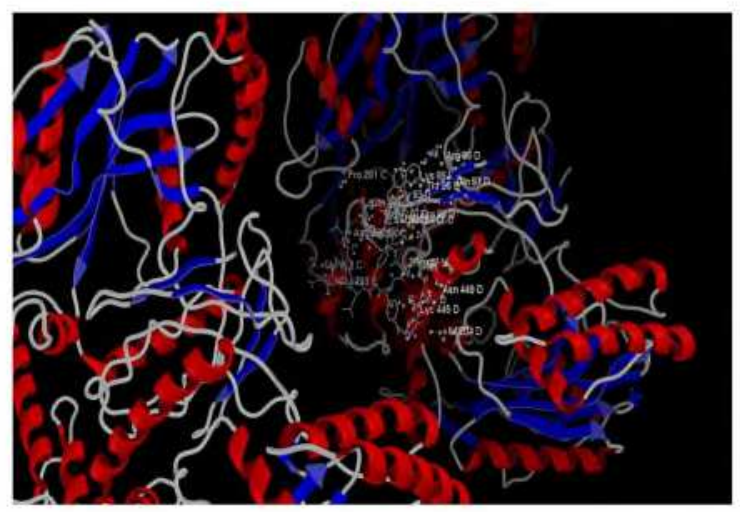

(a)

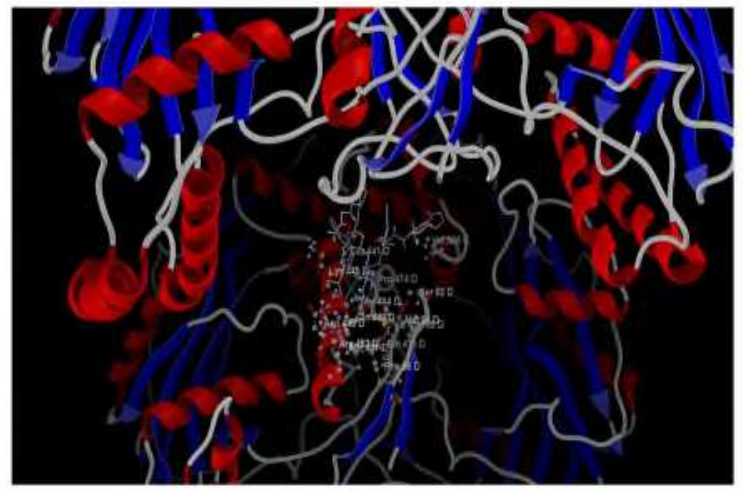

(c)

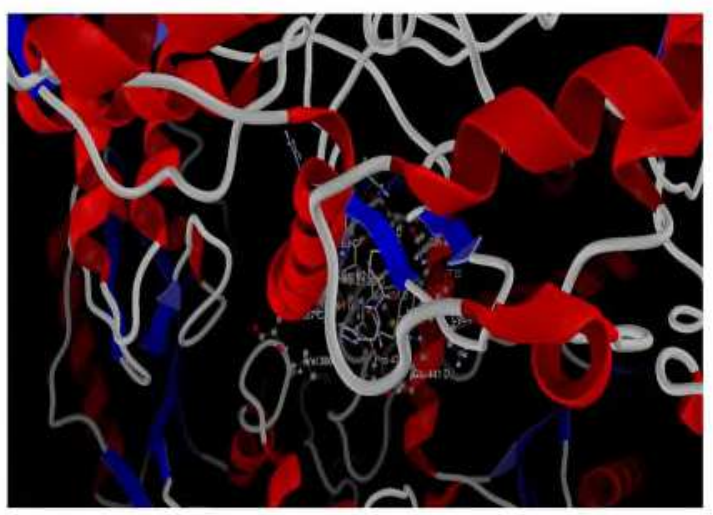

(b)

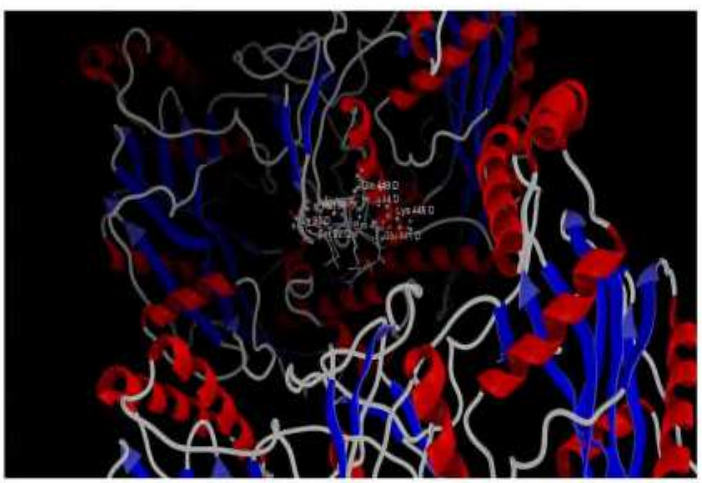

(d)

Fig.5Ligand docked against the crystal protein structure of NOS2 (a) Degarelix (b) Goserelin (c) Triptorelin pamoate (d) Venetoclax 


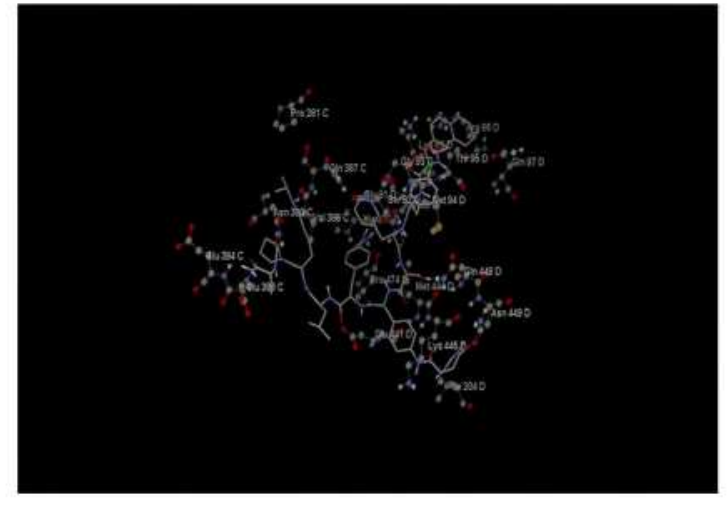

(a)

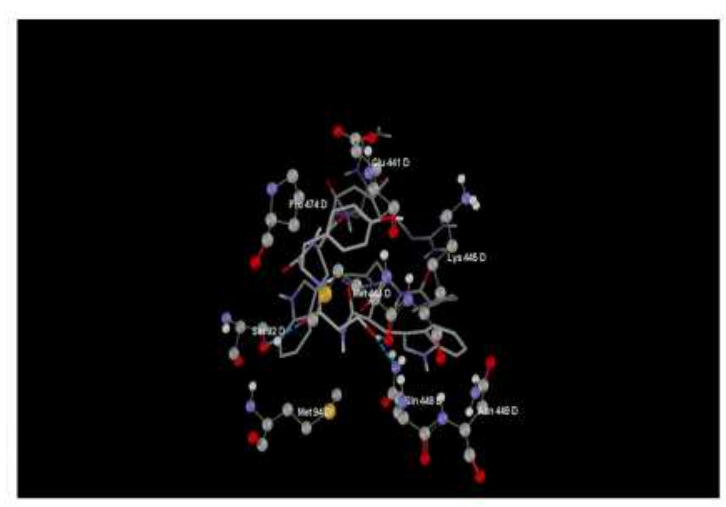

(c)

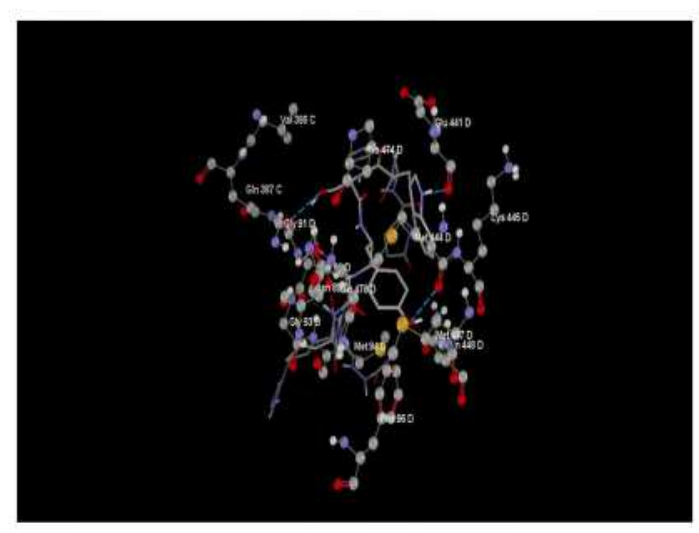

(b)

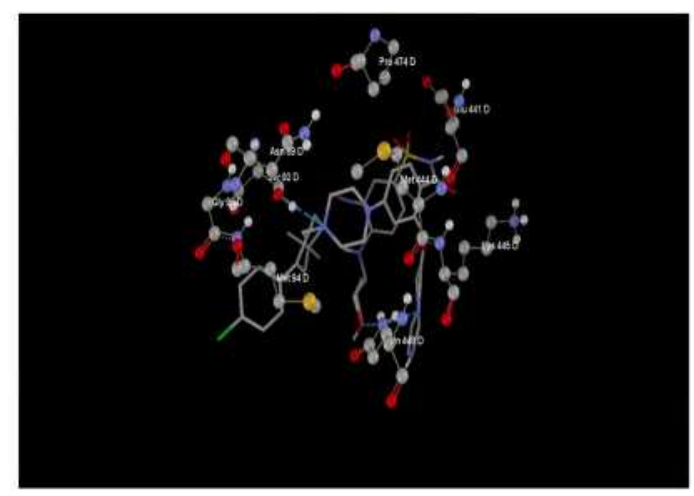

(d)

Fig.6The amino acid residues around active site and docked amino acids against NOS2 (a) Degarelix (b) Goserelin (c) Triptorelin pamoate (d) Venetoclax 


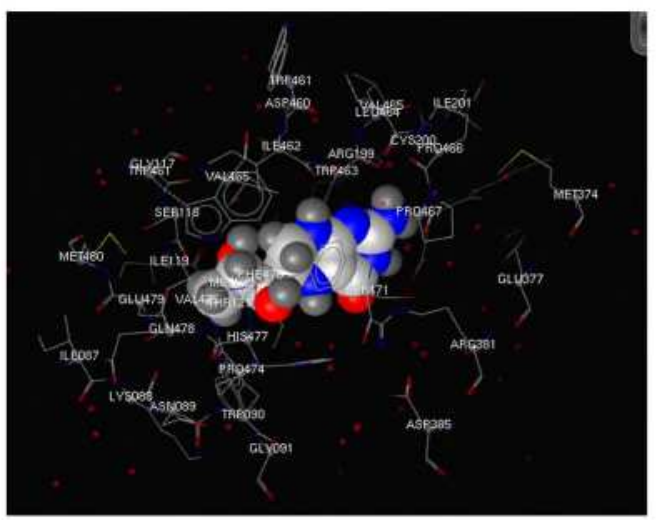

(a)

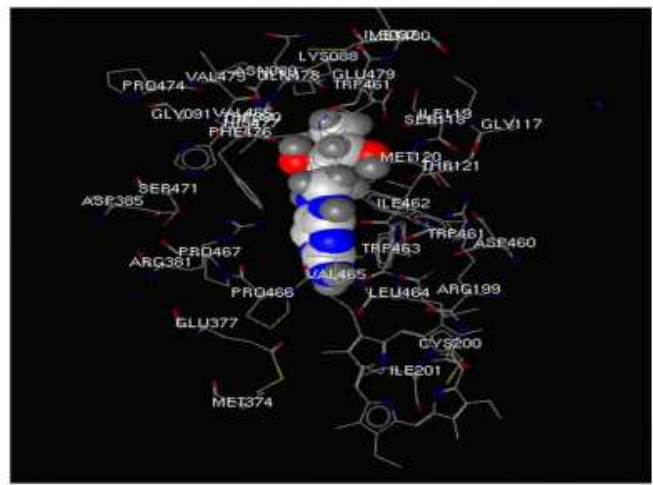

(c)

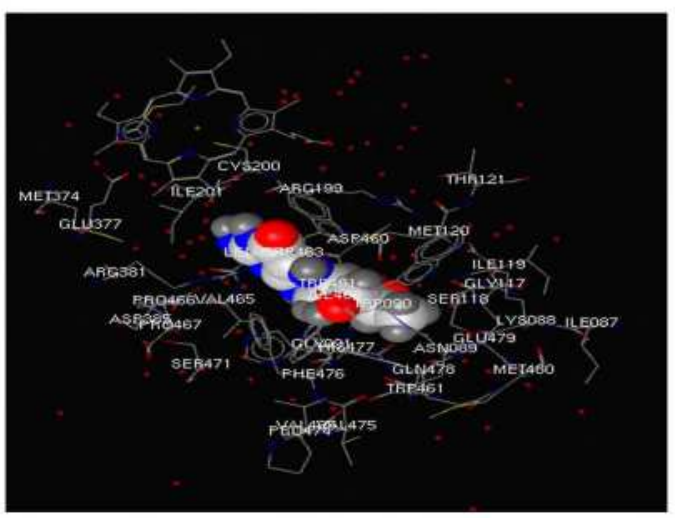

(b)

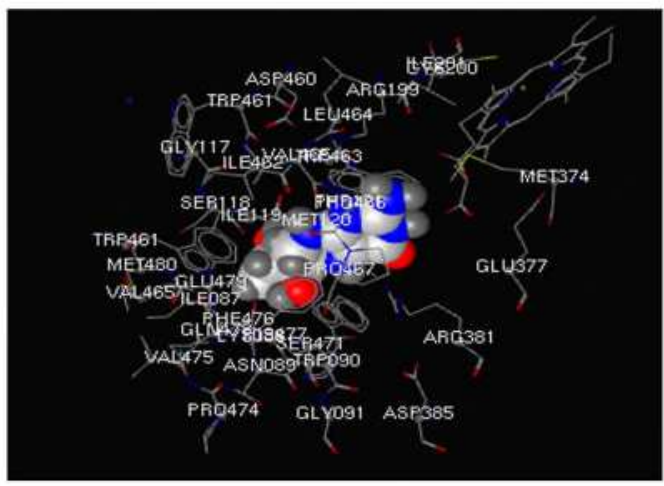

(d)

Fig.7pharmacophore models (a) Degarelix (b) Goserelin (c) Triptorelin pamoate (d) Venetoclax

\section{ADMET properties and Drug-likeness results}

A rapid dissociation rate will occur with the weaker binding, the more negative binding energy analogue to the strong binding of selected compounds to the target NOS2 protein[35]. The lower binding energy exhibited compounds gives the strong binding with NOS2 protein, the selected compounds have shown the lower binding energies. According to the Rule of Five, a molecule might be no longer orally active if it violates or greater than the 4 rules[36]. To obtain the pharmacophore properties ligands canonical smiles were uploadedto pkCSM, swissADME, and Molinspiration cheminformatics tools, and the results are illustrated in Table 4 


\section{DISCUSSION}

The enzyme NOS2 also called inducible NOS or inflammatory NOS plays a critical role in inflammation and tissue damage in cancer cells[37]. Docking studies have proved to be an essential tool to discover and identify the potential target candidates for a particular protein[38]. In this study FDA-approved anti-cancer drugs and small molecules were used to identify the potential inhibitor for human inducible nitric oxide synthase protein. Among 162 docked compounds we have identified 4 compounds that showed better inhibitory effect on NOS2.

The first compound Degarelix sold under the brand name of Firmagon is a gonadotrophinreleasing hormone antagonist used in the first-line treatment of advanced prostate cancer[39]. It has shown thelowest MolDock score, Rerank score, and better H-bondingenergy with NOS2 protein which is $-226.10 \mathrm{kcal} / \mathrm{mol},-106.48 \mathrm{kcal} / \mathrm{mol}$, and $-10.57 \mathrm{kcal} / \mathrm{mol}$ respectively.

The second compound Goserelin sold under the brand name Zoladex and it reduces the oestrogen levels in premenopausal women by inhibiting the hypothalamic-pituitary-ovarian axis[40]. It is a luteinizing hormone-releasing hormone antagonist widely used in the treatment of Breast cancer[41]. It has shown the lowest MolDock score, Rerank score, and H-bonding energy with NOS2 protein which has $-189.77 \mathrm{kcal} / \mathrm{mol},-92.09 \mathrm{kcal} / \mathrm{mol}$, and $-7.7 \mathrm{kcal} / \mathrm{mol}$ respectively.

The third selected compound Triptorelin pamoatesold under the brand name of Decapeptyl or Gonapeptyl and is a gonadotrophin-releasing hormone agonist. It is widely used in the palliative treatment of advanced prostate cancer[42], adjuvant treatment with the combination of tamoxifenTriptorelin pamoate in the early stage of Breast cancer[43]. It has shown the lowest MolDock score $-185.73 \mathrm{kcal} / \mathrm{mol}$, Rerank score $-59.99 \mathrm{kcal} / \mathrm{mol}$, and H-bonding energy $-10.24 \mathrm{kcal} / \mathrm{mol}$ with NOS2 protein.

The fourth compound venetoclax sold under the brand name of Venclexta and it is an antineoplastic agent which blocks BCL-2 and promotes apoptosis in various cancer cells[44]. In docking it has shown the lowest MolDock score $-168.21 \mathrm{kcal} / \mathrm{mol}$, Rerank score $-64.67 \mathrm{kcal} / \mathrm{mol}$, and H-bonding energy $-5.23 \mathrm{kcal} / \mathrm{mol}$ with NOS2 protein. All these drug candidates are widely using in the treatment of various cancers. Thus this study identified the 4 best inhibitory compounds from FDA-approved anti-cancer drugs and small molecules to inhibit NOS2 protein in cervical cancer. However further in-vitro and in-vivo studies are warranted to validate the promising potential of these compounds to be used as NOS2 protein inhibitors to restrain the cervical cancer progression. 


\section{Findings}

1. The key amino acids of NOS2 protein which are forming H-bonding interactions with ligands are Asn449D, Met94D, Ser92D, Pro474D, Val386C, Asn89D, Glu441D, Gly91D, Met444D, and Glu448D.

2. The common amino acid Ser92D is involved in all ligand interactions and forms H-bonding with ligands. So, from this we deduce that the amino acid Ser92D of NOS2 protein has the highest binding efficiency to form H-bonding with ligands.

3. The key amino acids which are involved in steric interactions are Val386C, Ser92D, Met94D, Met444D, Lys445D, Gln448D, Phe96D, Arg452D, Glu97D, Glu393C, Asn390C, Asn449D, and ile204D.

4. Based on our in-silico analysis we conclude that Degarelix, Goserelin, Triptorelin pamoate, and Venetoclax exhibit the potential to effectively inhibit NOS2 expression in cervical cancer.

\section{CONCLUSION}

In summary, FDA-approved anti-cancer drugs and small molecules from the PubChem, zinc database, and drug bank were docked against NOS2 protein. Molecular docking studies revealed that Degarelix, Goserelin, Triptorelin pamoate, and Venetoclax drugs interacted with human inducible nitric oxide synthase (NOS2) protein. These ligands demonstrate an excellent inhibitory binding effect on NOS2 and are potential candidates to be used as drugs to reduce iNOS expression in cervical cancer tumor cells. These results open the way for further experimental confirmation as a drug repurposing approach for NOS2 inhibitor to combat cervical cancer. 


\section{DECLARATIONS}

\section{Data availability}

Data supporting the productivity of this investigation are available from the corresponding author upon request.

\section{Conflict of interests}

The authors declare that there is no conflict of interest. No additional benefits will be received from a third party directly or indirectly by the authors.

\section{Author's contributions}

SCP \& PKP conceptualized, designed interpreted data and edited manuscript; PKP, AP, DP, SDA, SB, SMP, DK designed and conducted the study. All authors have approved the manuscript in the current form.

\section{Acknowledgments}

Thankful to the staff of the Department of Genetics \& Biotechnology, Osmania University for providing the Bioinformatics/software facilities.

\section{Funding}

This study was supported by grants of Dr. Smita C. Pawar received from the Science and Engineering Research Board(SERB), Govt. of India, reference Nos. SB/EMEQ-471/2014 and EEQ/2019/000569 dt 06-Jan-2020, and the fellowship was provided by DHR/HRD/Women Scientist/TypeV to SDA, by CFMT: RUSA 2.0 to DK, by CSIR-UGC to PKB \& AP, by ICMR to SB. The facilities were provided by DSTPURSE-II.

\section{Ethical approval}

Not applicable 


\section{Consent to participate}

Not applicable

\section{Consent to publish}

Not applicable 
Table 1Ligand structural information and after single point and geometry optimization energy minimization calculations

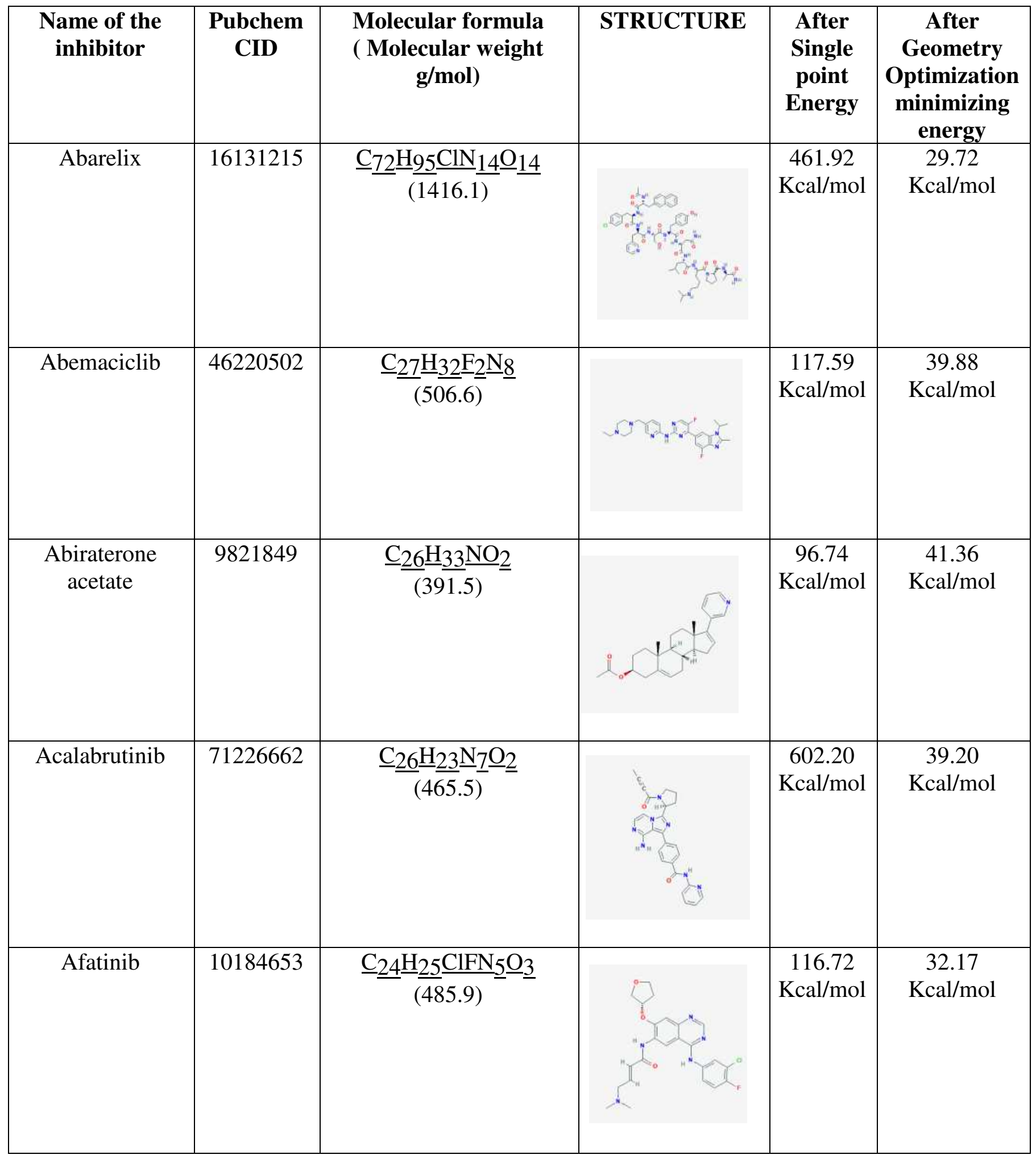




\begin{tabular}{|c|c|c|c|c|c|}
\hline $\begin{array}{c}\text { Afatinib } \\
\text { dimaleate }\end{array}$ & 15606394 & $\underline{\mathrm{C}_{32}} \underline{\underline{\mathrm{H}}} \frac{\mathrm{H}_{33}}{(718.1)} \frac{\mathrm{ClFN}_{5}}{\mathrm{O}_{11}}$ & & $\begin{array}{c}116.71 \\
\text { Kcal/mol }\end{array}$ & $\begin{array}{c}32.17 \\
\mathrm{Kcal} / \mathrm{mol}\end{array}$ \\
\hline Alectinib & 49806720 & $\underline{\mathrm{C}_{30}} \underline{\mathrm{H}_{3}} \underline{34} \underline{\mathrm{N}_{4}} \underline{\mathrm{O}_{2}} \underline{2}$ & & $\begin{array}{c}357.92 \\
\mathrm{Kcal} / \mathrm{mol}\end{array}$ & $\begin{array}{c}46.84 \\
\mathrm{Kcal} / \mathrm{mol}\end{array}$ \\
\hline Alimta & 135916113 & 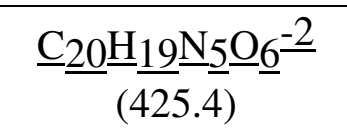 & & $\begin{array}{c}126.05 \\
\mathrm{Kcal} / \mathrm{mol}\end{array}$ & $\begin{array}{c}23.31 \\
\mathrm{Kcal} / \mathrm{mol}\end{array}$ \\
\hline Alpelisib & 56649450 & $\underline{\mathrm{C}} \underline{19} \underline{\mathrm{H}_{2}} \underline{\underline{2}} \underset{(441.5)}{\mathrm{F}_{3}} \underline{\mathrm{N}} \underline{5} \underline{\mathrm{O}} \underline{2} \underline{\mathrm{S}}$ & & $\begin{array}{c}145.89 \\
\text { Kcal/mol }\end{array}$ & $\begin{array}{c}38.96 \\
\mathrm{Kcal} / \mathrm{mol}\end{array}$ \\
\hline Amifostine & 2141 & $\underline{\mathrm{C}} \underline{5} \underline{\mathrm{H}_{1}} \underline{15} \underline{\mathrm{N}_{2}} \underline{\mathrm{O}_{3}} \underline{3} \underline{\mathrm{PS}}$ & & $\begin{array}{c}60.35 \\
\mathrm{Kcal} / \mathrm{mol}\end{array}$ & $\begin{array}{c}27.52 \\
\mathrm{Kcal} / \mathrm{mol}\end{array}$ \\
\hline Anagrelide & 135409400 & $\underline{\mathrm{C}_{1}} \underline{10} \underline{(25} \underline{\mathrm{H}} \underline{\mathrm{H}} \underline{\mathrm{Cl}} \underline{2} \underline{\mathrm{N}} \underline{\mathrm{N}} \underline{3} \underline{\mathrm{O}}$ & & $\begin{array}{c}49.61 \\
\text { Kcal/mol }\end{array}$ & $\begin{array}{c}13.98 \\
\mathrm{Kcal} / \mathrm{mol}\end{array}$ \\
\hline
\end{tabular}




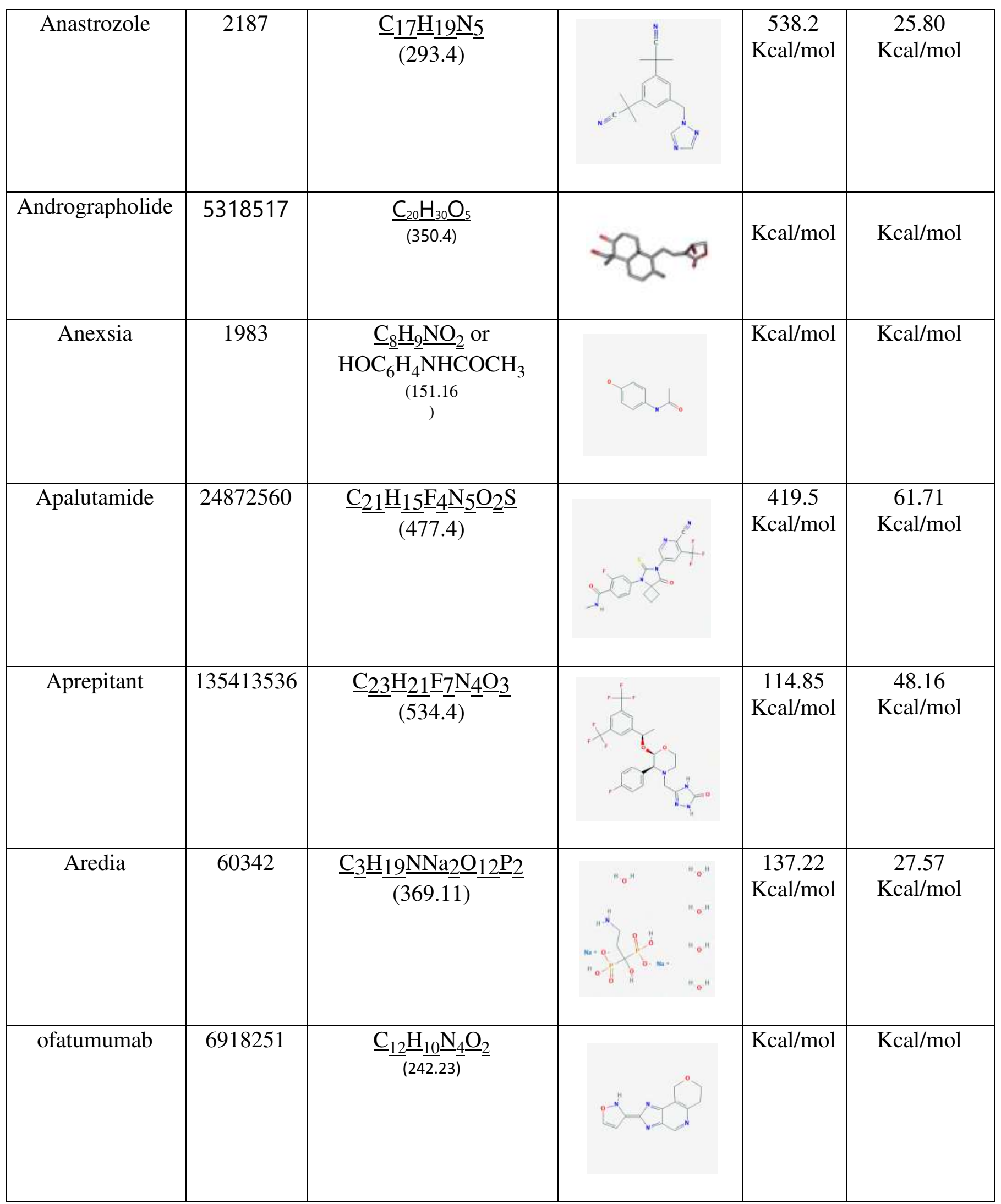




\begin{tabular}{|c|c|c|c|c|c|}
\hline Axitinib & 6450551 & 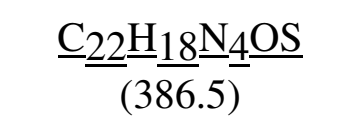 & & $\begin{array}{c}117.47 \\
\text { Kcal/mol }\end{array}$ & $\begin{array}{c}30.09 \\
\mathrm{Kcal} / \mathrm{mol}\end{array}$ \\
\hline Belinostat & 6918638 & 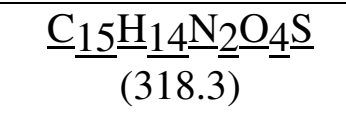 & & $\begin{array}{c}135.17 \\
\mathrm{Kcal} / \mathrm{mol}\end{array}$ & $\begin{array}{c}35.57 \\
\mathrm{Kcal} / \mathrm{mol}\end{array}$ \\
\hline Bendamustine & 65628 & $\underline{\mathrm{C}_{16}} \underline{\mathrm{H}_{21}} \underset{(358.3)}{\left(\mathrm{Cl}_{2}\right.} \underline{\mathrm{N}_{3}} \underline{\mathrm{O}_{2}} \underline{2}$ & & $\begin{array}{c}72.08 \\
\text { Kcal/mol }\end{array}$ & $\begin{array}{c}25.61 \\
\mathrm{Kcal} / \mathrm{mol}\end{array}$ \\
\hline Besponsa & 135298753 & $\underline{0635715014}$ & & $\mathrm{Kcal} / \mathrm{mol}$ & $\mathrm{Kcal} / \mathrm{mol}$ \\
\hline Binimetinib & 10288191 & $\underline{\mathrm{C}_{1}} \underline{17} \underline{\mathrm{H}_{15}} \underline{\underline{15}} \frac{\mathrm{BrF}_{2}}{(441.2)} \underline{\underline{N}} \underline{4} \underline{\mathrm{O}_{3}} \underline{3}$ & & $\begin{array}{c}99.41 \\
\mathrm{Kcal} / \mathrm{mol}\end{array}$ & $\begin{array}{c}40.68 \\
\mathrm{Kcal} / \mathrm{mol}\end{array}$ \\
\hline Bortezomib & 387447 & $\underline{\mathrm{C}_{1}} \underline{19} \underset{(384.2)}{\mathrm{H}_{25}} \underline{\mathrm{BN}} \underline{\mathrm{BN}_{4}} \underline{\mathrm{O}_{4}}$ & & $\begin{array}{c}119.28 \\
\mathrm{Kcal} / \mathrm{mol}\end{array}$ & $\begin{array}{c}8.73 \\
\mathrm{Kcal} / \mathrm{mol}\end{array}$ \\
\hline
\end{tabular}




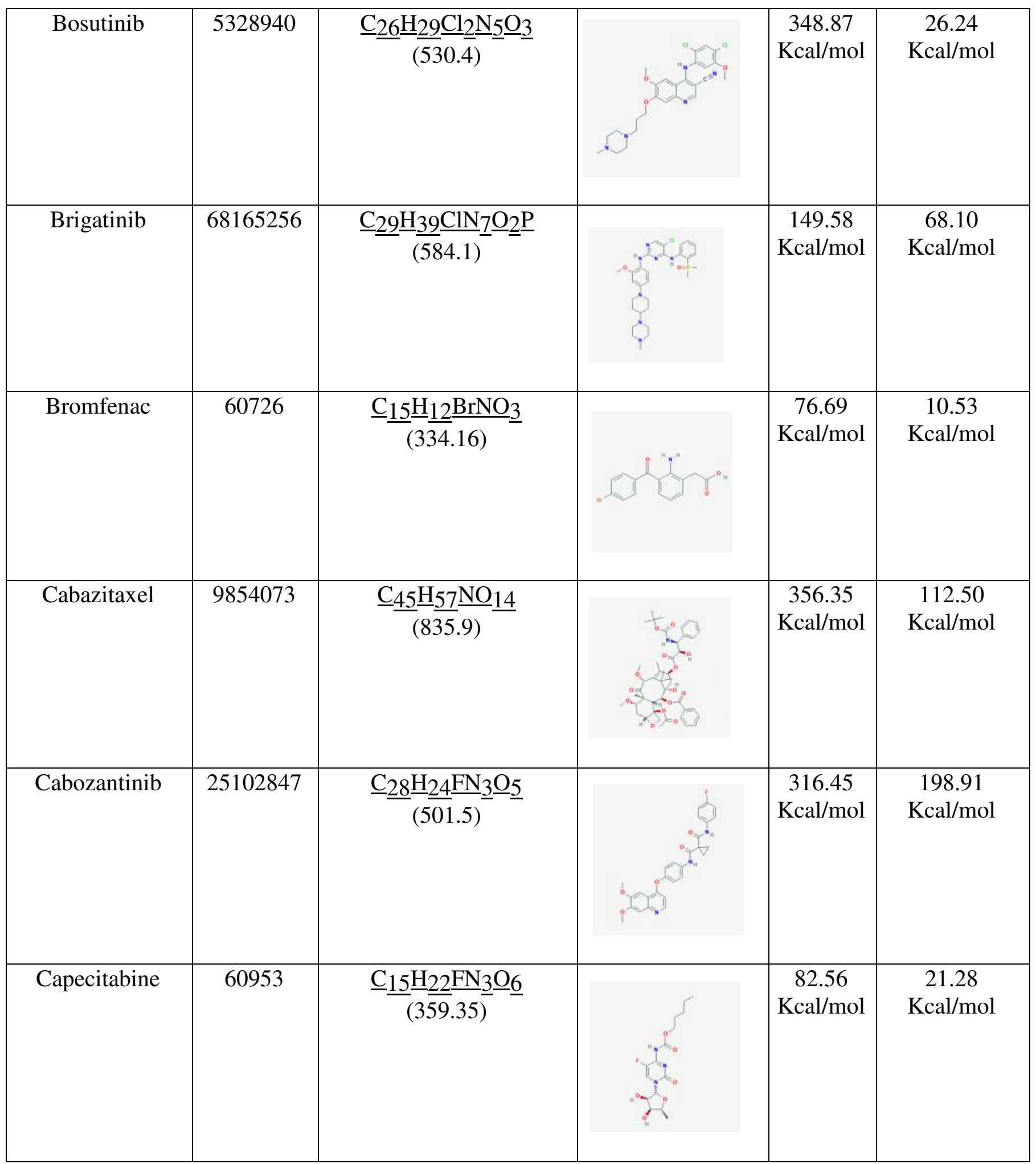




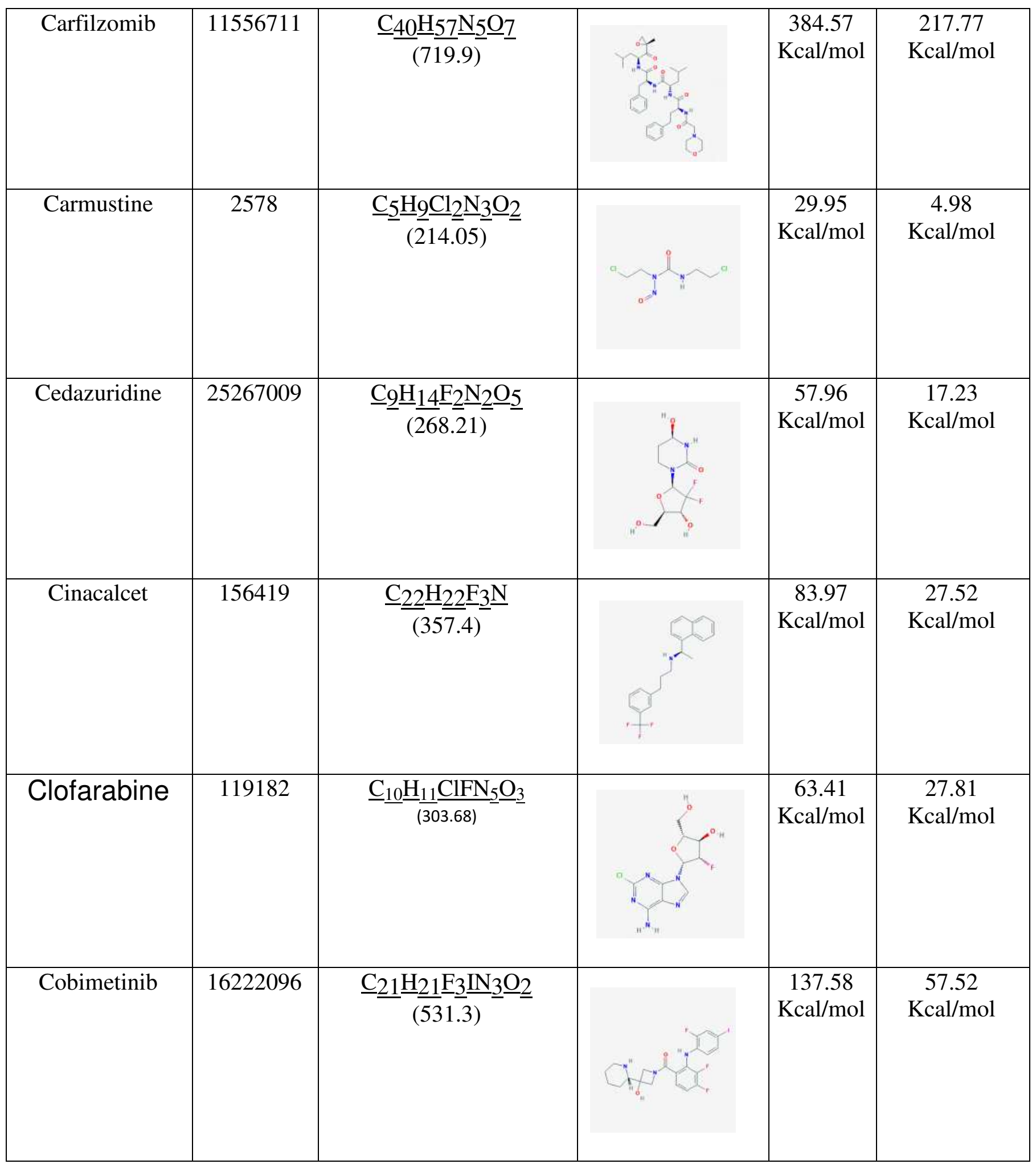




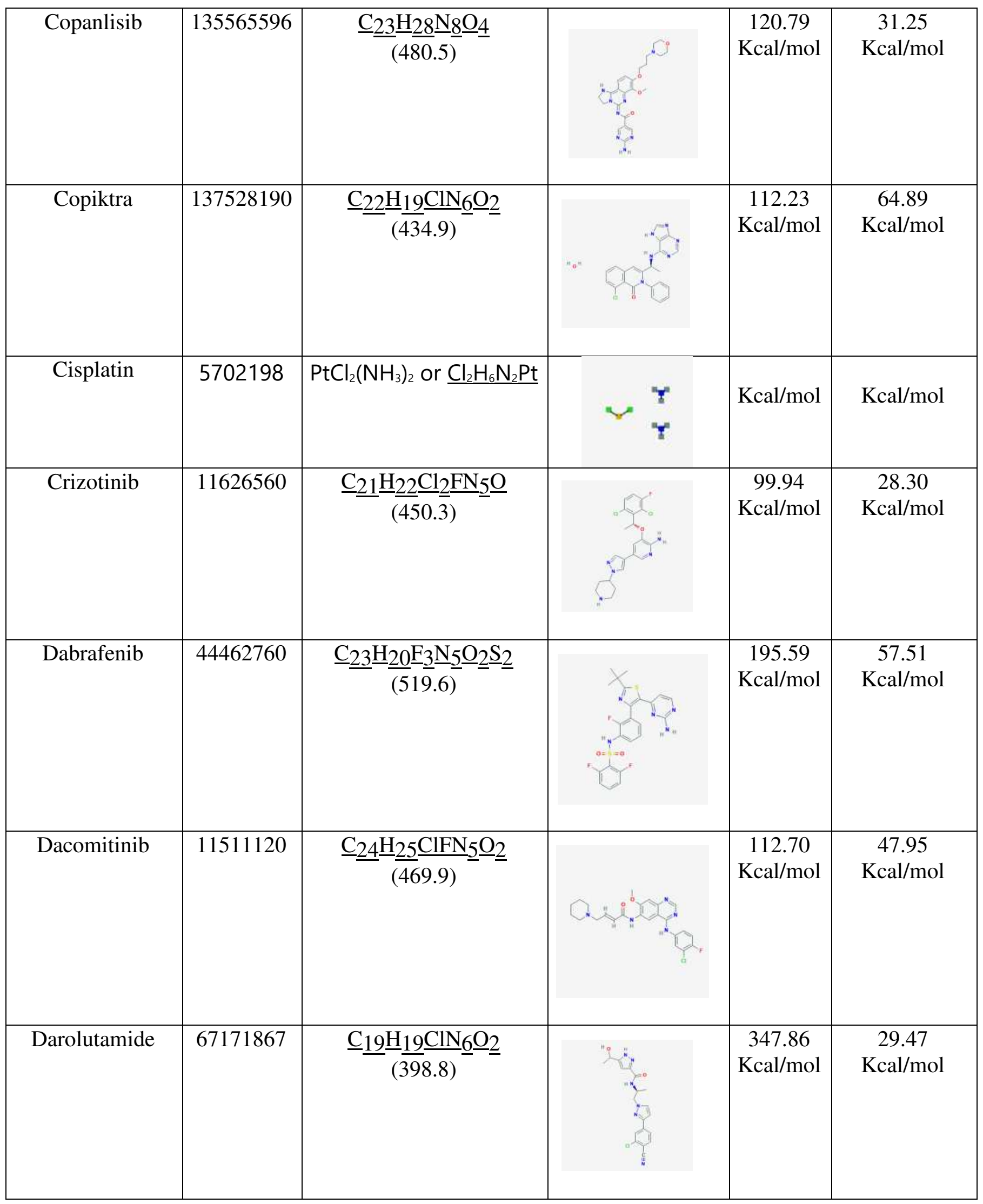




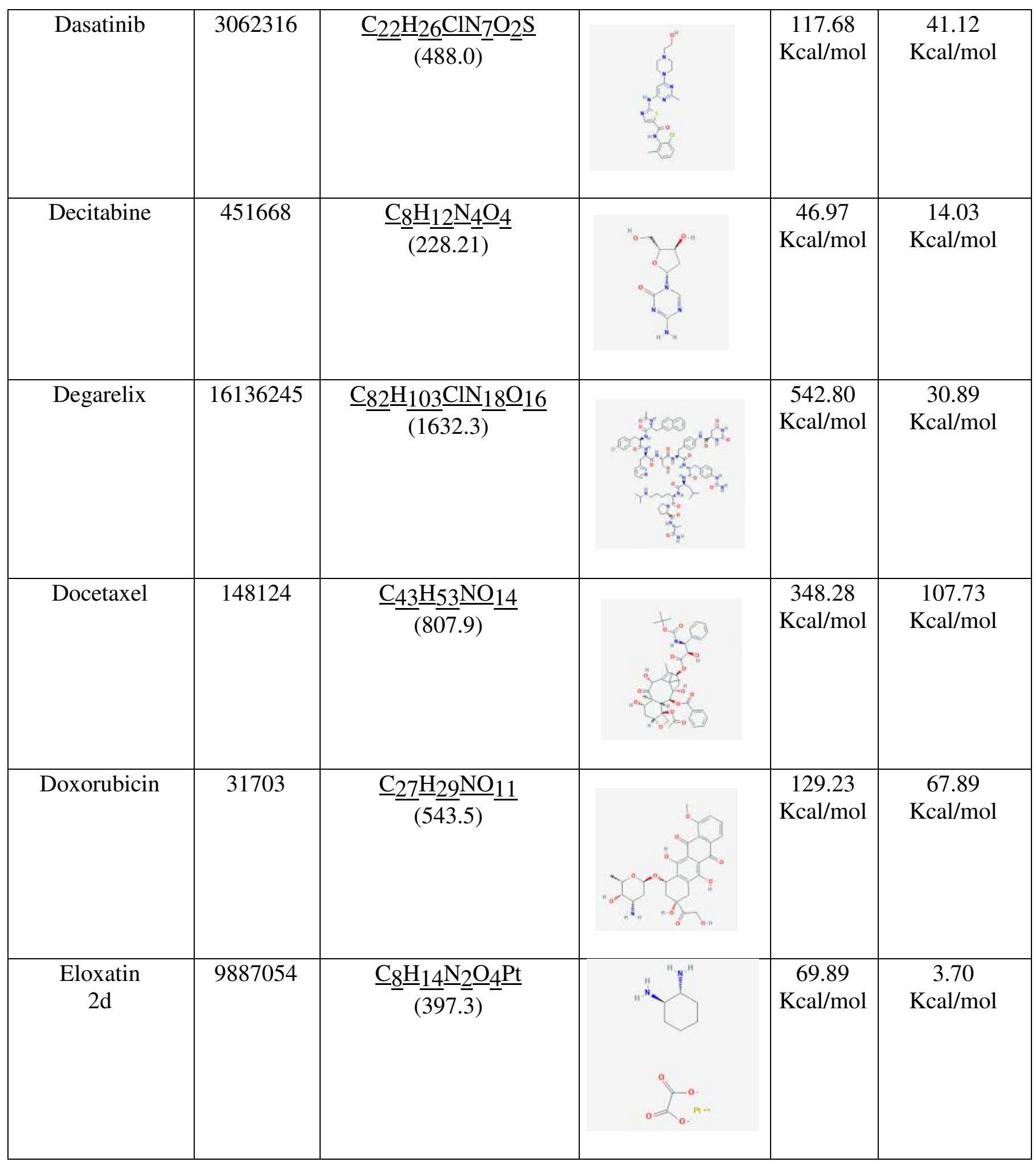




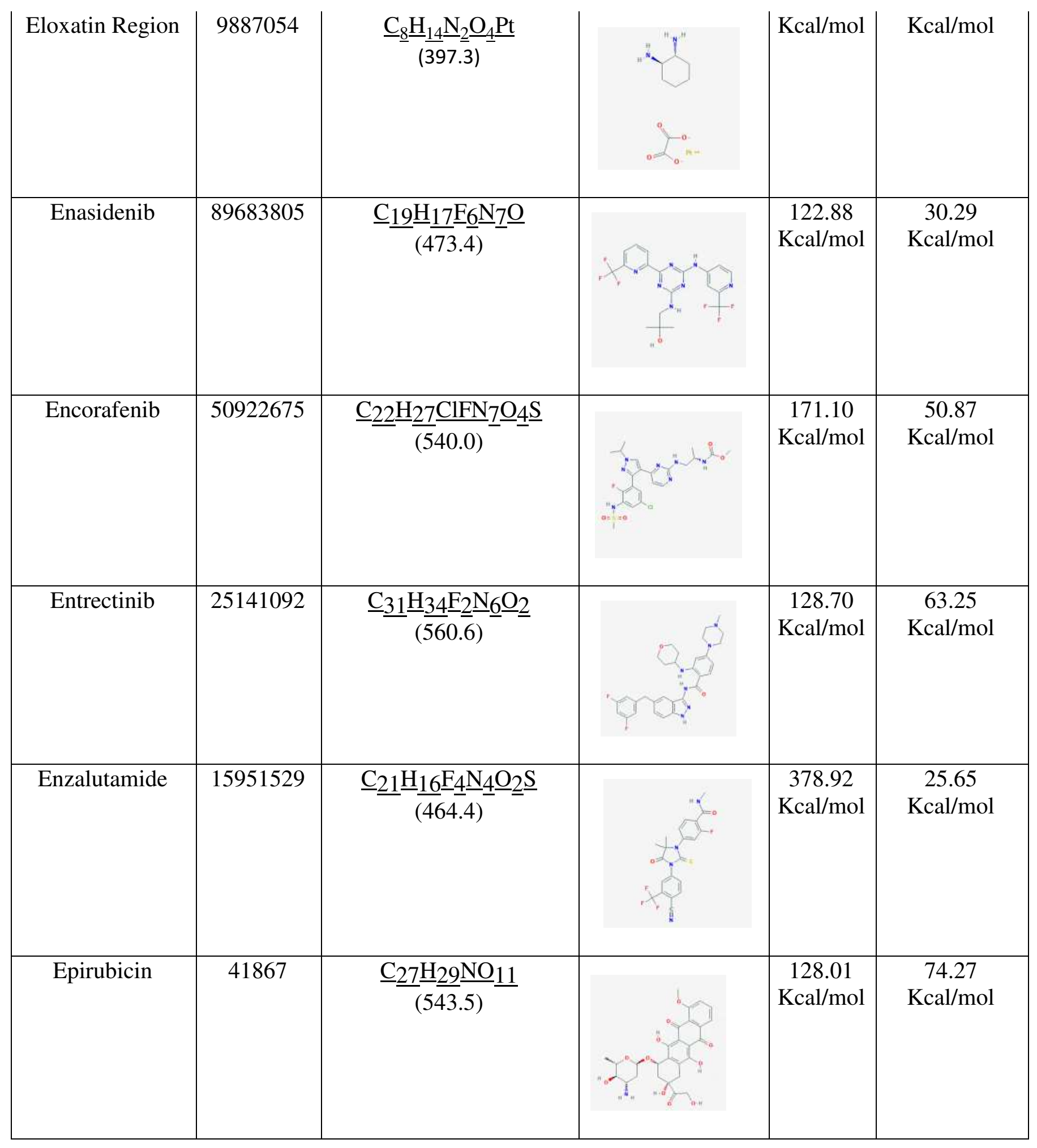




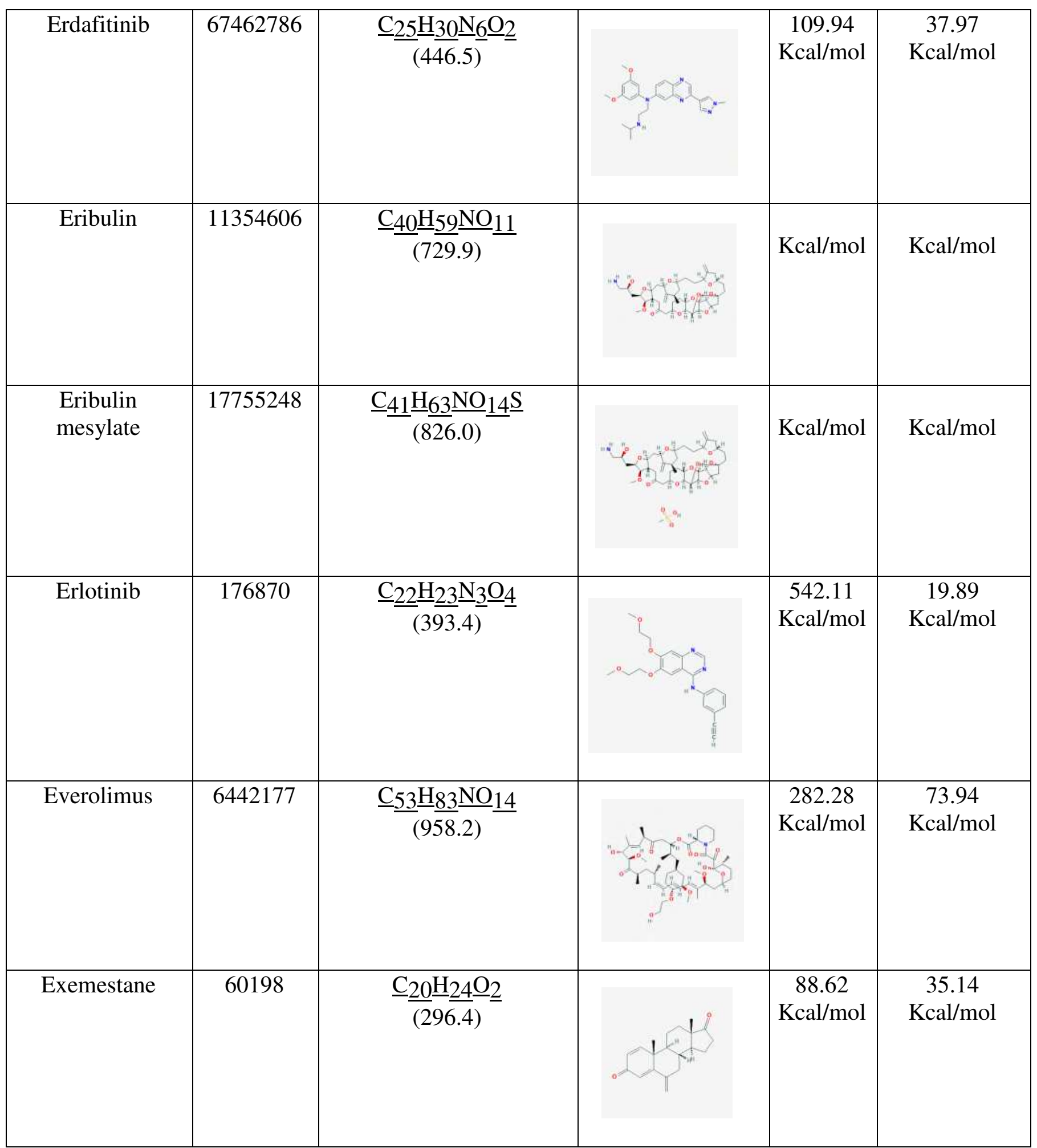




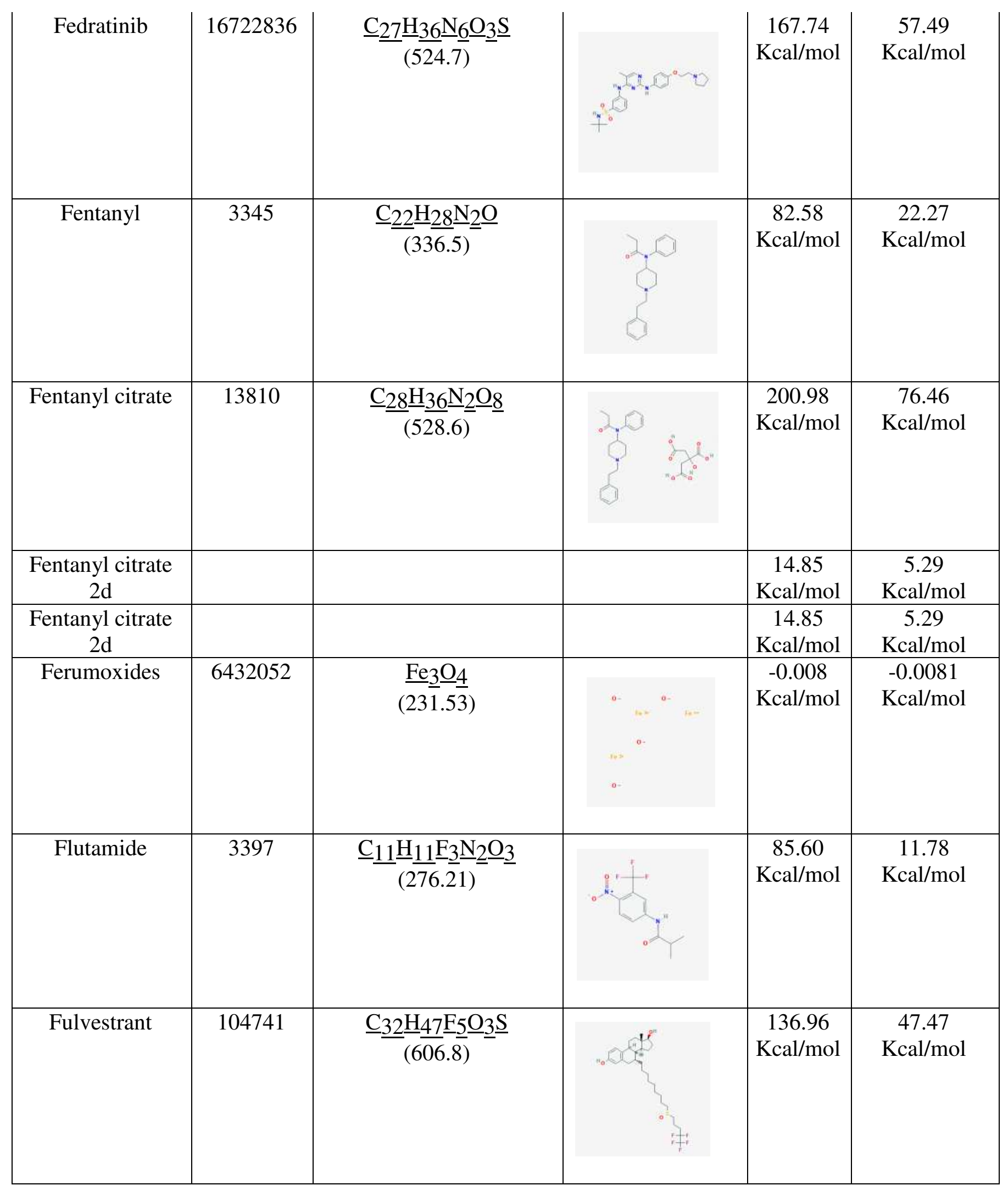




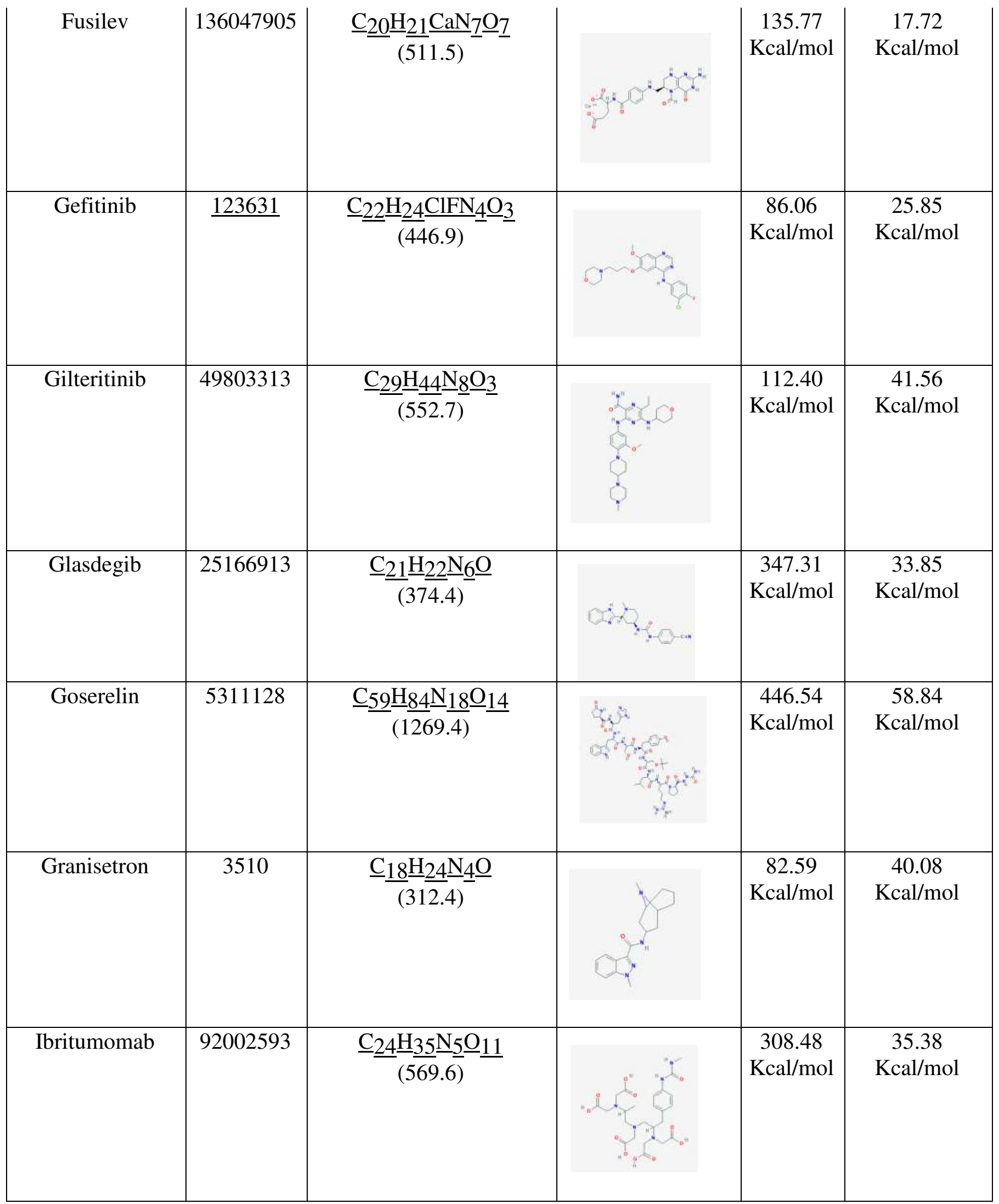




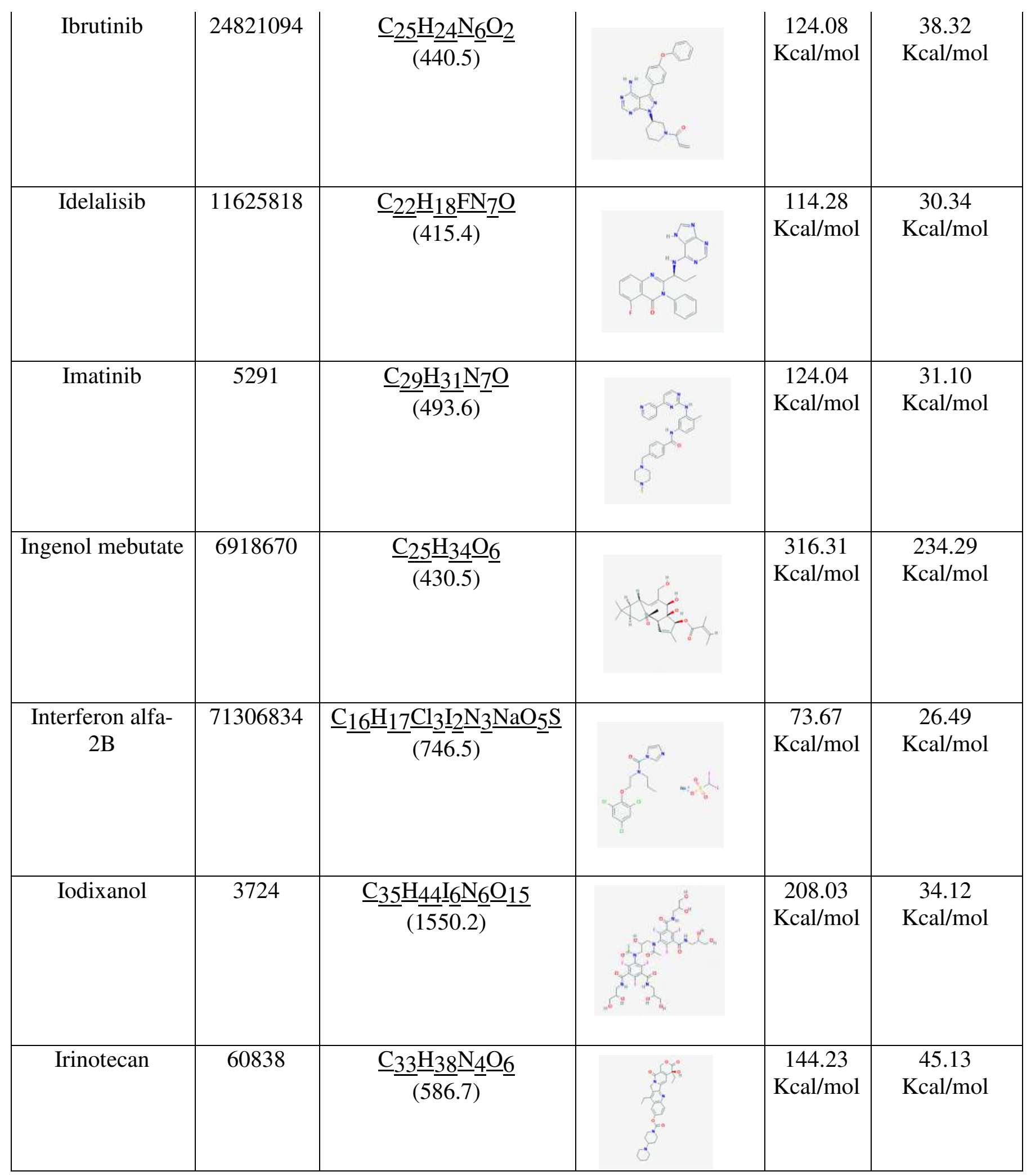




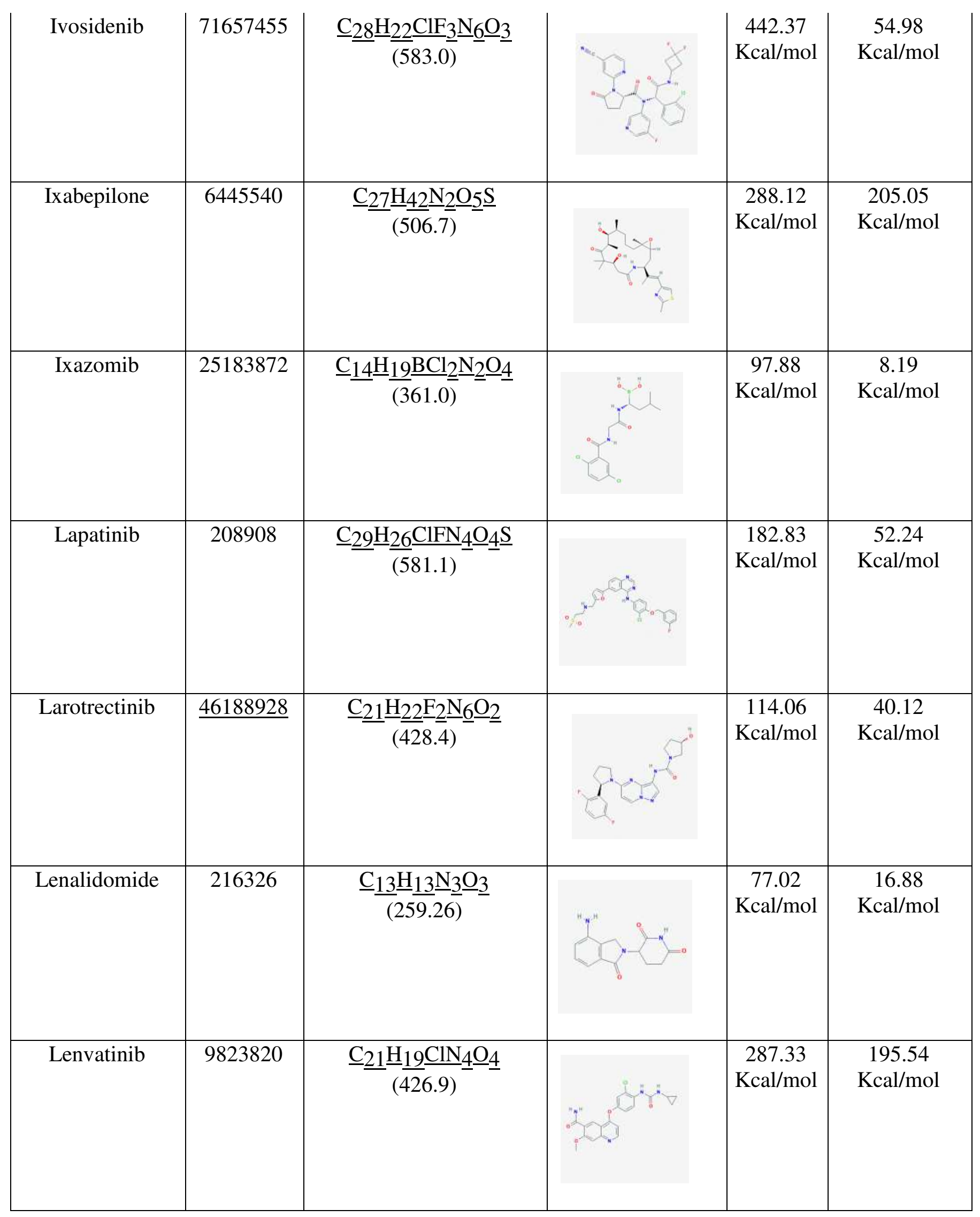




\begin{tabular}{|c|c|c|c|c|c|}
\hline Letrozole & 3902 & $\underline{\mathrm{C}}_{17} \underline{\mathrm{H}}_{(285.30)} \underline{\mathrm{N}} \underline{\mathrm{N}}$ & & $\begin{array}{c}583.27 \\
\mathrm{Kcal} / \mathrm{mol}\end{array}$ & $\begin{array}{c}17.03 \\
\mathrm{Kcal} / \mathrm{mol}\end{array}$ \\
\hline $\begin{array}{l}\text { Leuprolide } \\
\text { acetate }\end{array}$ & 657180 & 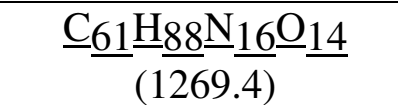 & & $\begin{array}{c}432.43 \\
\text { Kcal/mol }\end{array}$ & $\begin{array}{c}55.15 \\
\text { Kcal } / \mathrm{mol}\end{array}$ \\
\hline Leuprorelin & 657181 & $\underline{\mathrm{C}} \underline{59} \underline{\mathrm{H}_{84}} \underline{\underline{(1209}} \underline{\underline{N}} \underline{16} \underline{\mathrm{O}} \underline{12}$ & & $\begin{array}{c}414.72 \\
\text { Kcal/mol }\end{array}$ & $\begin{array}{c}55.26 \\
\mathrm{Kcal} / \mathrm{mol}\end{array}$ \\
\hline Levoleucovorin & 135398559 & 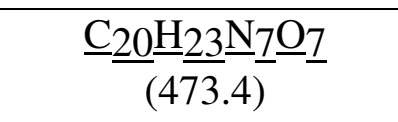 & & $\begin{array}{c}135.77 \\
\mathrm{Kcal} / \mathrm{mol}\end{array}$ & $\begin{array}{c}17.72 \\
\mathrm{Kcal} / \mathrm{mol}\end{array}$ \\
\hline Lonsurf & 9829639 & 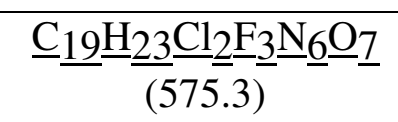 & & $\begin{array}{c}142.01 \\
\mathrm{Kcal} / \mathrm{mol}\end{array}$ & $\begin{array}{c}24.02 \\
\mathrm{Kcal} / \mathrm{mol}\end{array}$ \\
\hline Lorlatinib & 71731823 & $\underline{\mathrm{C}_{21}} \underline{\underline{\mathrm{H}}} \underline{19} \underline{{ }_{(4)}} \underline{\mathrm{FN}} \underline{6} \underline{\underline{\mathrm{O}}} \underline{2}$ & & $\begin{array}{c}351.30 \\
\mathrm{Kcal} / \mathrm{mol}\end{array}$ & $\begin{array}{c}29.98 \\
\mathrm{Kcal} / \mathrm{mol}\end{array}$ \\
\hline Lutathera & 132274234 & 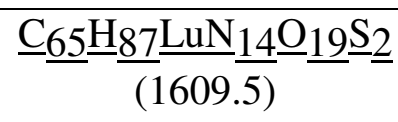 & & $\mathrm{Kcal} / \mathrm{mol}$ & $\mathrm{Kcal} / \mathrm{mol}$ \\
\hline
\end{tabular}




\begin{tabular}{|c|c|c|c|c|c|}
\hline $\begin{array}{c}\text { Magnesium } \\
\text { silicate, hydrous }\end{array}$ & 16211421 & $\begin{array}{c}\underline{\mathrm{H}}_{2} \underline{\mathrm{Mg}_{3}} \underline{\mathrm{O}_{12}} \underline{\mathrm{Si}_{4}} \text { or } \\
\mathrm{Mg}_{3}(\mathrm{OH})_{2} \underline{\mathrm{Si}}_{4} \mathrm{O}_{10} \text { or } \\
\mathrm{Mg}_{3}\left(\mathrm{Si}_{4} \mathrm{O}_{10}\right)(\mathrm{OH})_{2} \\
(379.27)\end{array}$ & 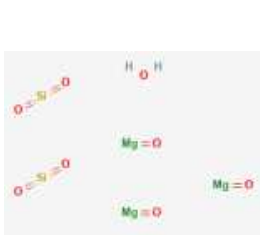 & $\begin{array}{c}1683.13 \\
\text { Kcal/mol }\end{array}$ & $\begin{array}{c}0.03 \\
\mathrm{Kcal} / \mathrm{mol}\end{array}$ \\
\hline Marqibo & 138911098 & 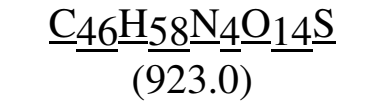 & & $\begin{array}{c}494.99 \\
\mathrm{Kcal} / \mathrm{mol}\end{array}$ & $\begin{array}{c}148.72 \\
\text { Kcal/mol }\end{array}$ \\
\hline Mechlorethamine & 4033 & $\underline{\mathrm{C}} \underline{5} \underline{\mathrm{H}} 111 \underline{\mathrm{H}_{2}} \underline{\mathrm{Cl}_{2}} \underline{\mathrm{N}}$ & & $\begin{array}{c}16.04 \\
\mathrm{Kcal} / \mathrm{mol}\end{array}$ & $\begin{array}{c}9.36 \\
\mathrm{Kcal} / \mathrm{mol}\end{array}$ \\
\hline $\begin{array}{l}\text { Melphalan } \\
\text { flufenamide }\end{array}$ & 9935639 & $\underline{\mathrm{C}}_{2} \underline{4} \underline{\mathrm{H}_{3}} \underline{\underline{30}} \underline{\mathrm{Cl}_{2}} \underline{\mathrm{FN}_{3}} \underline{\mathrm{FN}_{3}} \underline{\mathrm{O}_{3}} \underline{3}$ & & $\begin{array}{c}88.32 \\
\mathrm{Kcal} / \mathrm{mol}\end{array}$ & $\begin{array}{c}8.47 \\
\mathrm{Kcal} / \mathrm{mol}\end{array}$ \\
\hline Methoxsalen & 4114 & $\begin{array}{l}\underline{\mathrm{C}}_{12} \underline{\mathrm{H}} \underline{8} \underline{\mathrm{O}} \underline{4} 4 \\
(216.19)\end{array}$ & & $\begin{array}{c}70.23 \\
\text { Kcal/mol }\end{array}$ & $\begin{array}{c}22.29 \\
\mathrm{Kcal} / \mathrm{mol}\end{array}$ \\
\hline Midostaurin & 9829523 & $\underline{\mathrm{C}_{35}} \underline{\mathrm{H}_{3}} \underline{30} \underline{(570.6)} \underline{\mathrm{N}_{4}} \underline{\mathrm{O}_{4}} \underline{4}$ & & $\begin{array}{c}212.05 \\
\text { Kcal/mol }\end{array}$ & $\begin{array}{c}79.99 \\
\mathrm{Kcal} / \mathrm{mol}\end{array}$ \\
\hline Miraluma & 449763 & $\underline{\mathrm{C}_{36}} \underline{\mathrm{H}_{6}} \underline{(777.9)} \underline{\mathrm{N}_{6}} \underline{\mathrm{O}} \underline{6} \underline{\mathrm{Tc}}$ & otace 0 & $\begin{array}{c}158.66 \\
\mathrm{Kcal} / \mathrm{mol}\end{array}$ & $\begin{array}{c}10.87 \\
\mathrm{Kcal} / \mathrm{mol}\end{array}$ \\
\hline
\end{tabular}




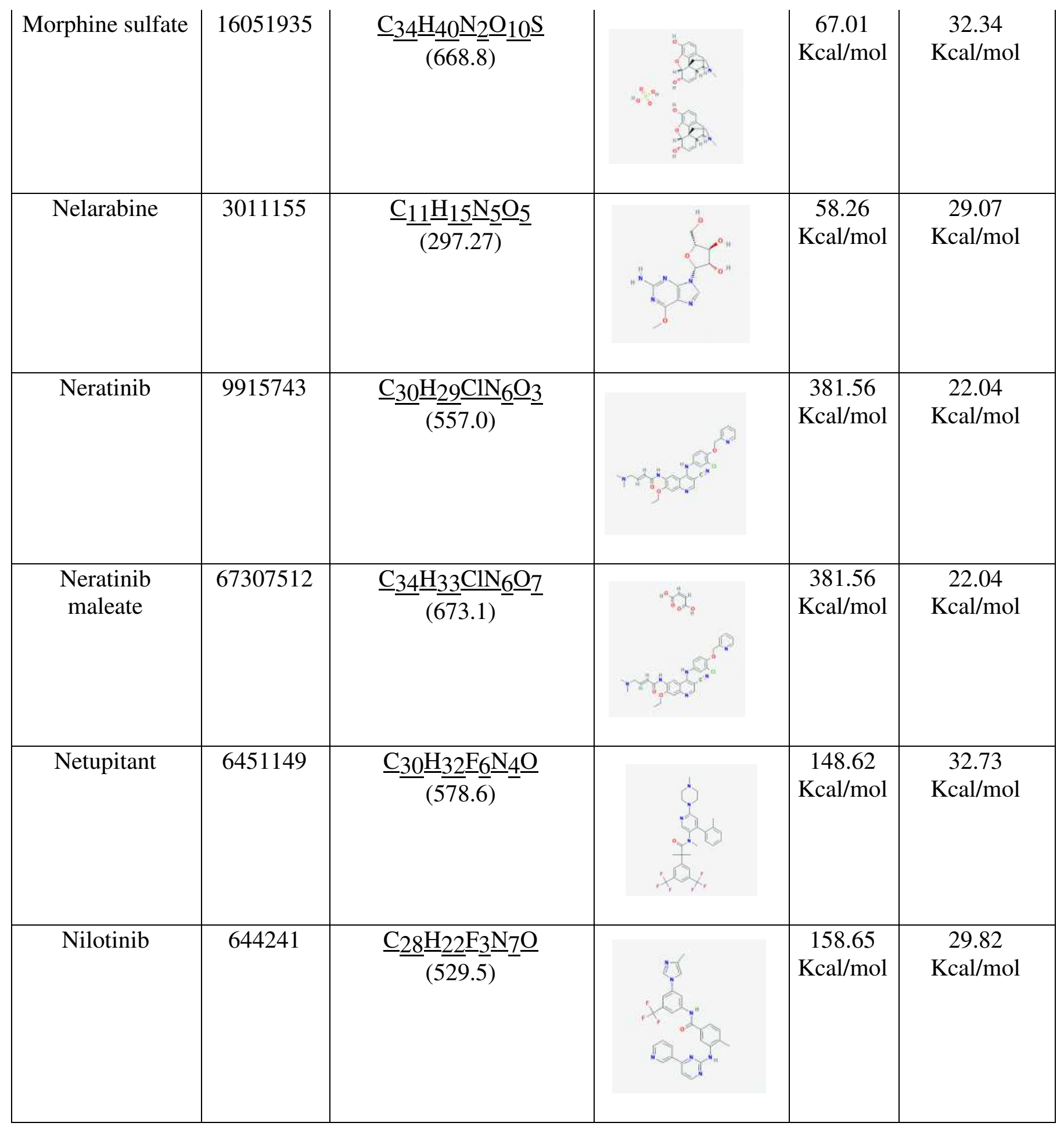




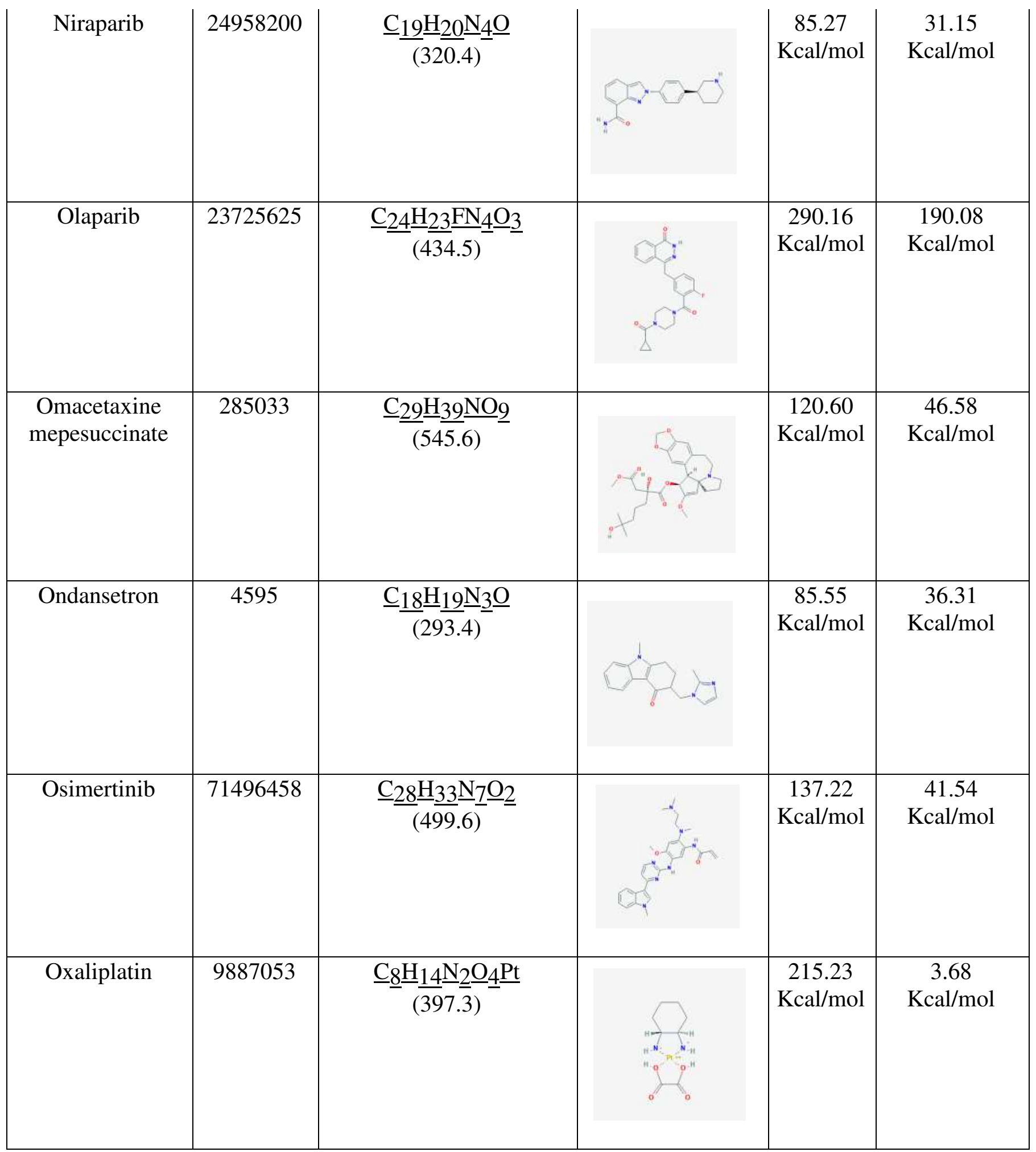




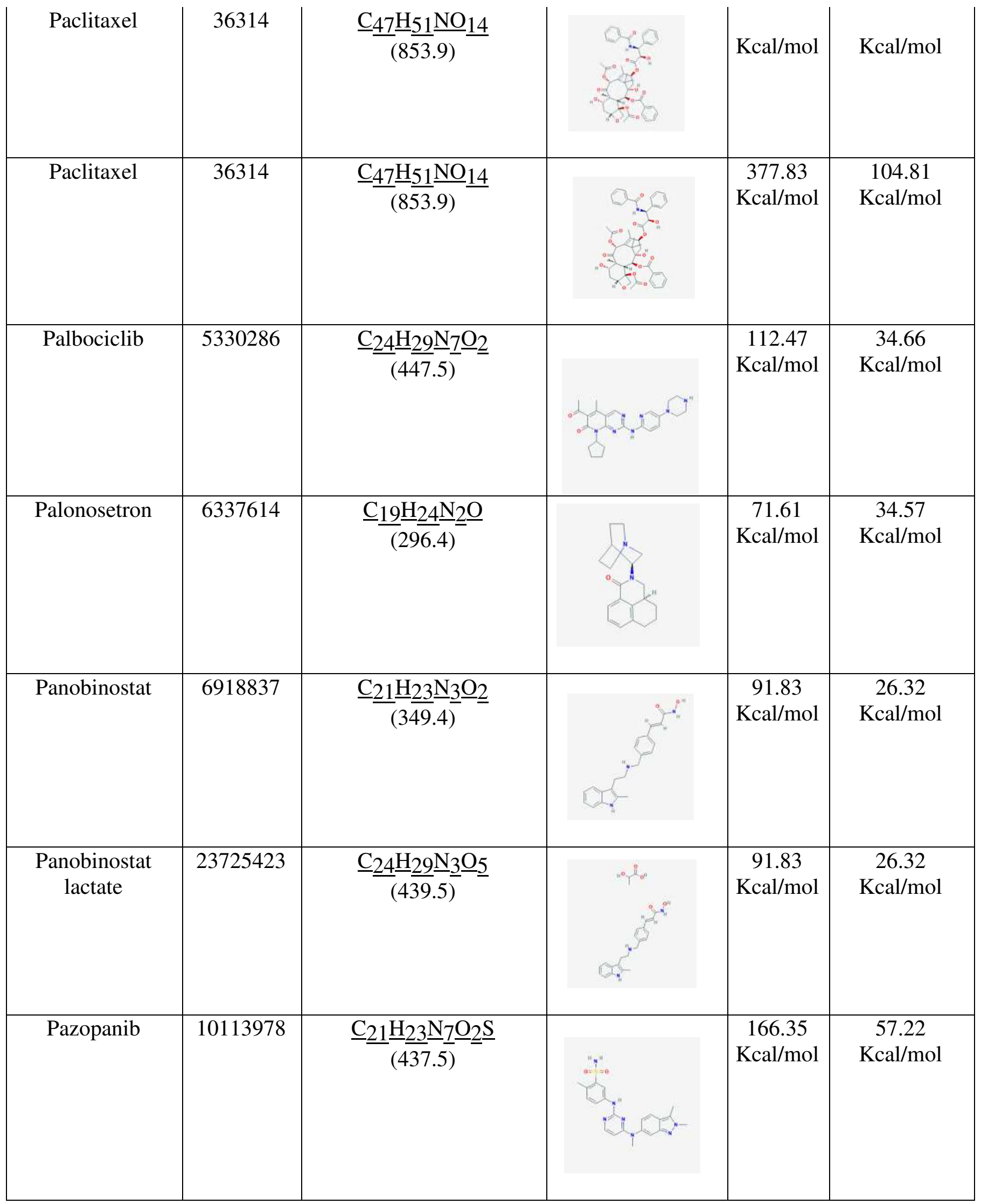




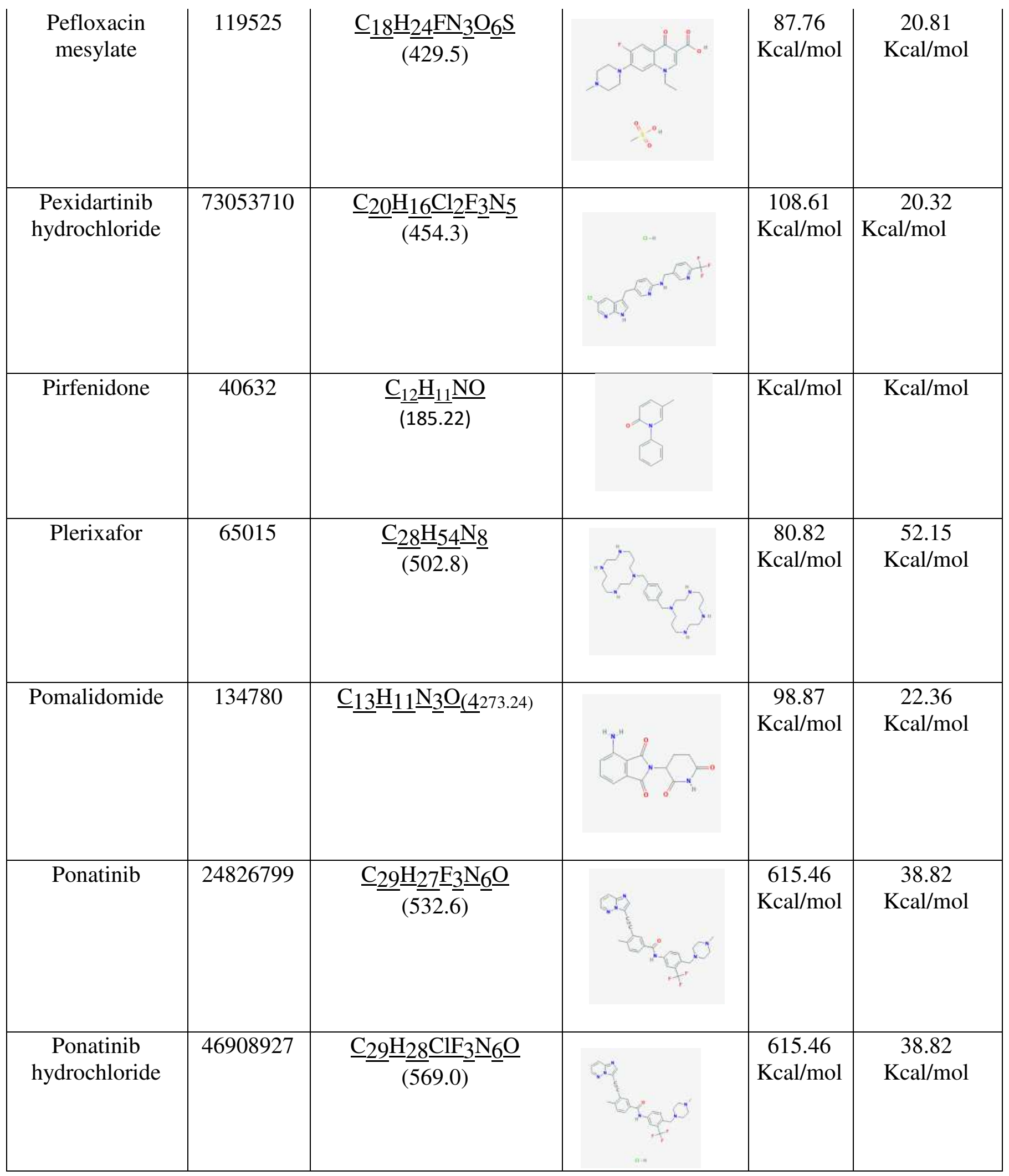




\begin{tabular}{|c|c|c|c|c|c|}
\hline Porfimer sodium & 137321858 & $\underline{\mathrm{C}_{3}} \underline{4} \underline{\underline{\mathrm{H}}} \underline{\underline{38}} \underline{\underline{\mathrm{N}} 4} \underline{\mathrm{NaO}_{5}} \underline{5}^{ \pm}$ & & $\begin{array}{c}187.59 \\
\mathrm{Kcal} / \mathrm{mol}\end{array}$ & $\begin{array}{c}60.68 \\
\mathrm{Kcal} / \mathrm{mol}\end{array}$ \\
\hline Pralatrexate & 148121 & 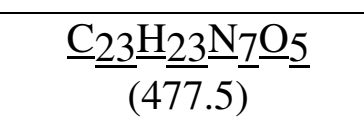 & & $\begin{array}{c}584.65 \\
\mathrm{Kcal} / \mathrm{mol}\end{array}$ & $\begin{array}{c}10.35 \\
\text { Kcal/mol }\end{array}$ \\
\hline Pralsetinib & 129073603 & $\underline{\mathrm{C}_{2} 7} \underset{(533.6)}{\underline{\mathrm{H}}} \underline{32} \underline{\mathrm{FN}} \underline{9} \underline{\mathrm{O}} \underline{2}$ & & $\begin{array}{c}140.80 \\
\text { Kcal/mol }\end{array}$ & $\begin{array}{c}41.37 \\
\mathrm{Kcal} / \mathrm{mol}\end{array}$ \\
\hline Premarin & 23667301 & $\underline{\mathrm{C}} \underline{18} \underline{\mathrm{H}_{2}} \underline{21} \underline{(372.4)} \underline{\mathrm{NaO}_{5}} \underline{\mathrm{S}}$ & & $\begin{array}{c}133.15 \\
\mathrm{Kcal} / \mathrm{mol}\end{array}$ & $\begin{array}{c}56.51 \\
\mathrm{Kcal} / \mathrm{mol}\end{array}$ \\
\hline Pregabalin & 5486971 & $\underline{\mathrm{C}}_{\underline{8}} \frac{\mathrm{H}_{17}}{(159.23)} \underline{\mathrm{NO}_{2}}$ & & $\mathrm{Kcal} / \mathrm{mol}$ & $\mathrm{Kcal} / \mathrm{mol}$ \\
\hline Quadramet & 6918027 & $\underline{\mathrm{C}_{6}} \underline{\mathrm{H}_{2}} \underline{20} \underline{\mathrm{N}_{2}} \underline{2} \underline{\mathrm{O}} \underline{12} \underline{12} \underline{\mathrm{P}} \underline{4} \underline{4} \underline{\mathrm{Sm}}$ & & $\begin{array}{c}231.74 \\
\mathrm{Kcal} / \mathrm{mol}\end{array}$ & $\begin{array}{c}99.44 \\
\mathrm{Kcal} / \mathrm{mol}\end{array}$ \\
\hline Raloxifene & 5035 & $\underline{\mathrm{C}_{2} 8} \underline{\mathrm{H}_{2}} \underset{273}{27} \underline{\mathrm{NO}_{4}} \underline{4} \underline{\mathrm{S}}$ & & $\begin{array}{c}133.38 \\
\text { Kcal/mol }\end{array}$ & $\begin{array}{c}39.35 \\
\mathrm{Kcal} / \mathrm{mol}\end{array}$ \\
\hline
\end{tabular}




\begin{tabular}{|c|c|c|c|c|c|}
\hline $\begin{array}{l}\text { Raloxifene } \\
\text { hydrochloride }\end{array}$ & 54900 & $\underline{\mathrm{C}_{2} 8} \underline{\mathrm{H}_{2}} \underset{(510.0)}{(510)} \underline{\mathrm{ClNO}_{4}} \underline{\mathrm{S}}$ & & $\begin{array}{c}133.38 \\
\mathrm{Kcal} / \mathrm{mol}\end{array}$ & $\begin{array}{c}39.35 \\
\mathrm{Kcal} / \mathrm{mol}\end{array}$ \\
\hline Regorafenib & 11167602 & $\underline{\mathrm{C}}_{21} \underline{\mathrm{H}_{1}} \underline{15} \underline{\mathrm{ClF}_{1}} \underline{4} \underline{\mathrm{N}_{4}} \underline{\mathrm{N}_{4}} \underline{\mathrm{O}} \underline{3}$ & & $\begin{array}{c}139.04 \\
\mathrm{Kcal} / \mathrm{mol}\end{array}$ & $\begin{array}{c}22.51 \\
\mathrm{Kcal} / \mathrm{mol}\end{array}$ \\
\hline Ribociclib & 44631912 & $\underline{\mathrm{C}} 233 \underline{\mathrm{H}} \underline{30} \underline{\mathrm{N}} \underline{8} \underline{\mathrm{O}}$ & & $\mathrm{Kcal} / \mathrm{mol}$ & $\mathrm{Kcal} / \mathrm{mol}$ \\
\hline Rolapitant & 10311306 & $\underline{\mathrm{C}_{2}} \underline{25} \underline{\mathrm{H}_{2}} \underline{26} \underline{\mathrm{F}} \underline{6} \underline{6} \underline{\mathrm{N}_{2}} \underline{\mathrm{N}_{2}} \underline{\mathrm{O}} \underline{2}$ & & $\begin{array}{c}126.69 \\
\text { Kcal/mol }\end{array}$ & $\begin{array}{c}25.03 \\
\text { Kcal/mol }\end{array}$ \\
\hline Romidepsin & 5352062 & $\underline{\mathrm{C}}_{24} \underline{\mathrm{H}_{3}} \underline{36} \underline{(540.7)} \underline{\underline{\mathrm{N}}} \underline{\underline{\mathrm{O}}} \underline{6} \underline{\mathrm{S}} \underline{\mathrm{S}} \underline{2}$ & & $\begin{array}{c}151.38 \\
\text { Kcal/mol }\end{array}$ & $\begin{array}{c}23.03 \\
\text { Kcal/mol }\end{array}$ \\
\hline Rucaparib & 9931954 & $\underline{\mathrm{C}} \underline{19} \underset{(323.4)}{1} \frac{\mathrm{H}}{18} \frac{\mathrm{FN}}{3} \underline{\mathrm{O}}$ & & $\begin{array}{c}88.16 \\
\text { Kcal/mol }\end{array}$ & $\begin{array}{c}30.15 \\
\mathrm{Kcal} / \mathrm{mol}\end{array}$ \\
\hline $\begin{array}{l}\text { Sacituzumab } \\
\text { govitecan }\end{array}$ & 91668186 & $\underline{\mathrm{C}}_{76} \underline{\mathrm{H}_{104}} \underline{\mathrm{H}}_{(1601} \underline{\mathrm{N}}_{12} \underline{\mathrm{O}}_{24} \underline{\mathrm{O}_{2}} \underline{\mathrm{S}}$ & & $\begin{array}{c}407.54 \\
\text { Kcal/mol }\end{array}$ & $\begin{array}{c}81.69 \\
\mathrm{Kcal} / \mathrm{mol}\end{array}$ \\
\hline
\end{tabular}




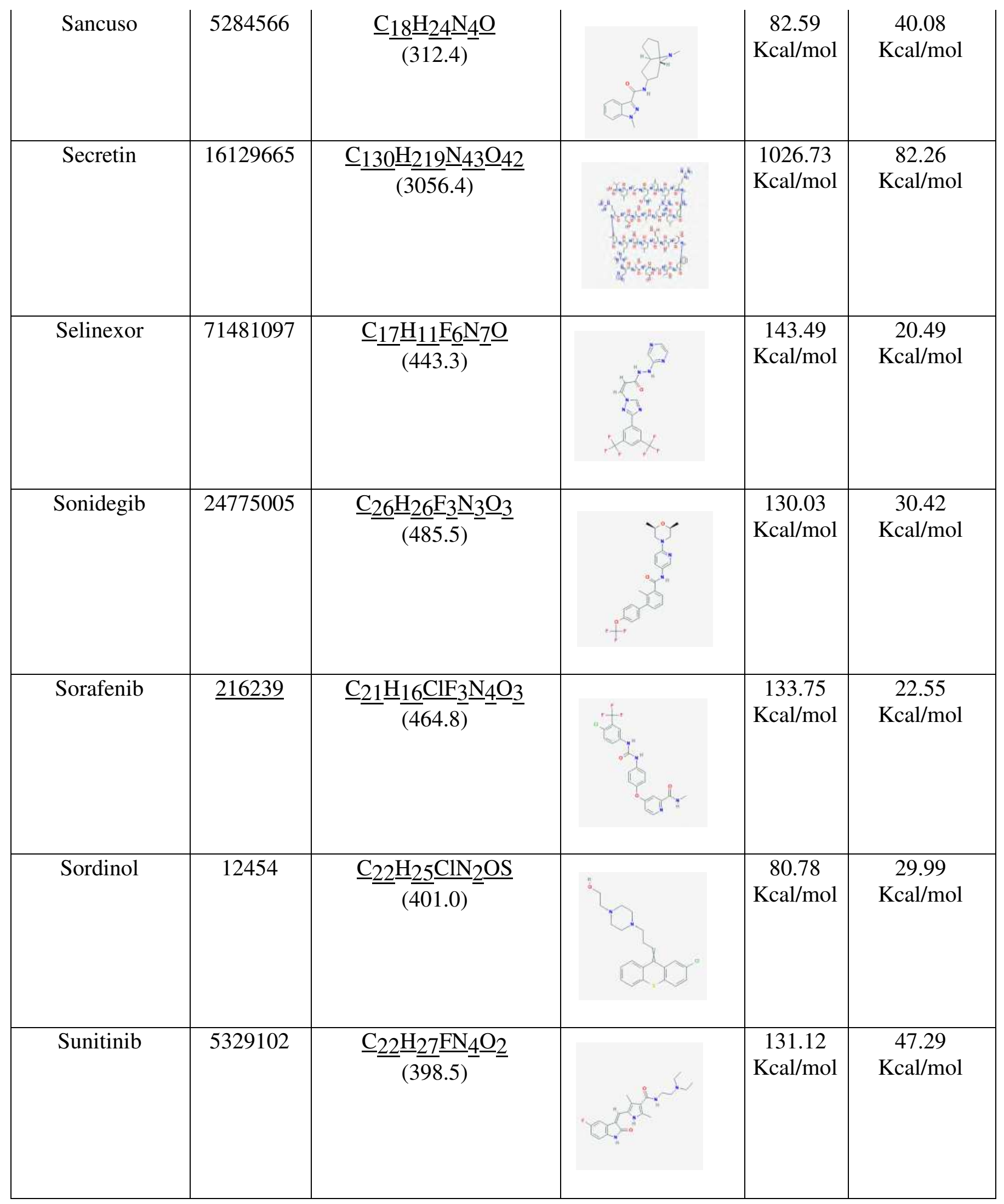




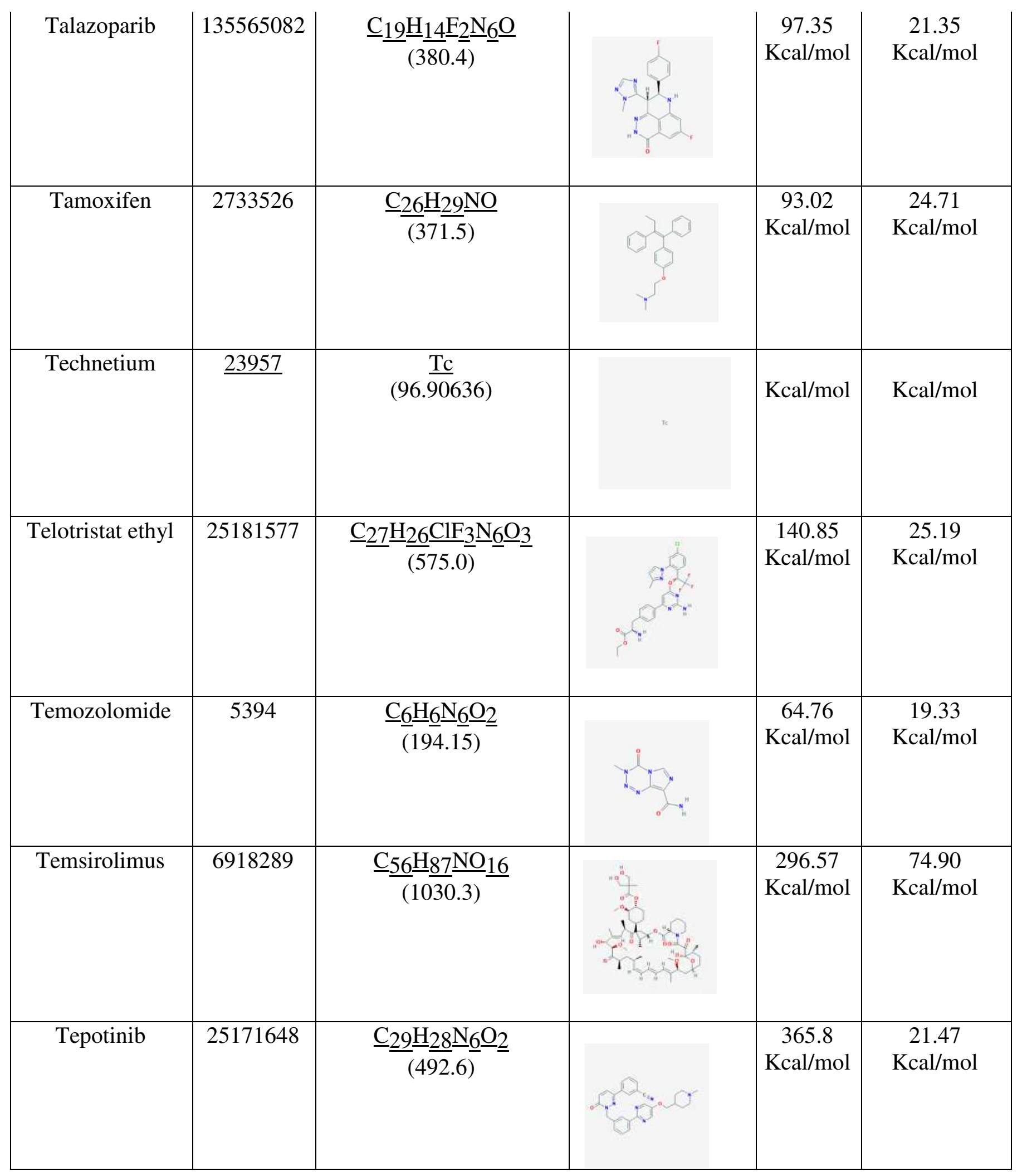




\begin{tabular}{|c|c|c|c|c|c|}
\hline Tivozanib & 9911830 & $\underline{\mathrm{C}}_{22} \underline{\mathrm{H}_{19}} \frac{{ }_{(4)}}{(45.9)} \underline{\mathrm{ClN}} \underline{4} \underline{\mathrm{O}} \underline{5}$ & & $\begin{array}{c}126.0 \\
\text { Kcal/mol }\end{array}$ & $\begin{array}{c}35.66 \\
\mathrm{Kcal} / \mathrm{mol}\end{array}$ \\
\hline $\begin{array}{c}\text { Tivozanib } \\
\text { hydrochloride }\end{array}$ & 11547978 & $\underline{\mathrm{C}}_{22} \underline{\mathrm{H}_{22}} \underset{(509.3)}{\mathrm{Cl}_{2}} \underline{\underline{\mathrm{N}}} \underline{4} \underline{\mathrm{O}} \underline{6}$ & & $\begin{array}{c}126.0 \\
\mathrm{Kcal} / \mathrm{mol}\end{array}$ & $\begin{array}{c}35.66 \\
\text { Kcal/mol }\end{array}$ \\
\hline Topotecan & 60700 & $\underline{\mathrm{C}} 23 \underline{\mathrm{H}} \underline{23} \underline{\mathrm{N}_{3}} \underline{\mathrm{O}} \underline{\mathrm{O}}$ & & $\begin{array}{c}111.58 \\
\mathrm{Kcal} / \mathrm{mol}\end{array}$ & $\begin{array}{c}28.14 \\
\mathrm{Kcal} / \mathrm{mol}\end{array}$ \\
\hline $\begin{array}{c}\text { Topotecan } \\
\text { hydrochloride }\end{array}$ & 60699 & $\underline{\mathrm{C}} \underline{23} \underline{\mathrm{H}_{24}} \frac{\mathrm{ClN}}{(457.9)} \underline{3} \underline{\mathrm{O}} \underline{5}$ & & $\begin{array}{c}111.58 \\
\mathrm{Kcal} / \mathrm{mol}\end{array}$ & $\begin{array}{c}28.14 \\
\text { Kcal/mol }\end{array}$ \\
\hline Trabectedin & 108150 & $\underline{\mathrm{C}} 3 \underline{9} \underline{\mathrm{H}} \underline{43} \underline{(76} \underline{\underline{\mathrm{N}}} \underline{\underline{\mathrm{O}}} \underline{\mathrm{O}} \underline{11} \underline{\mathrm{S}}$ & & $\mathrm{Kcal} / \mathrm{mol}$ & $\mathrm{Kcal} / \mathrm{mol}$ \\
\hline Trametinib & 11707110 & 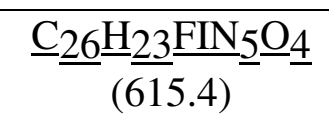 & & $\begin{array}{c}328.5 \\
\mathrm{Kcal} / \mathrm{mol}\end{array}$ & $\begin{array}{c}199.13 \\
\text { Kcal/mol }\end{array}$ \\
\hline $\begin{array}{c}\text { Trilaciclib } \\
\text { dihydrochloride }\end{array}$ & 124081865 & $\underline{\mathrm{C}_{24}} \underline{\mathrm{H}_{32}} \underline{\underline{\mathrm{H}_{2}}} \frac{\mathrm{Cl}}{(519.5)} \underline{\mathrm{N}_{8}} \underline{\mathrm{O}}$ & & $\begin{array}{c}106.6 \\
\text { Kcal/mol }\end{array}$ & $\begin{array}{c}44.28 \\
\text { Kcal/mol }\end{array}$ \\
\hline
\end{tabular}




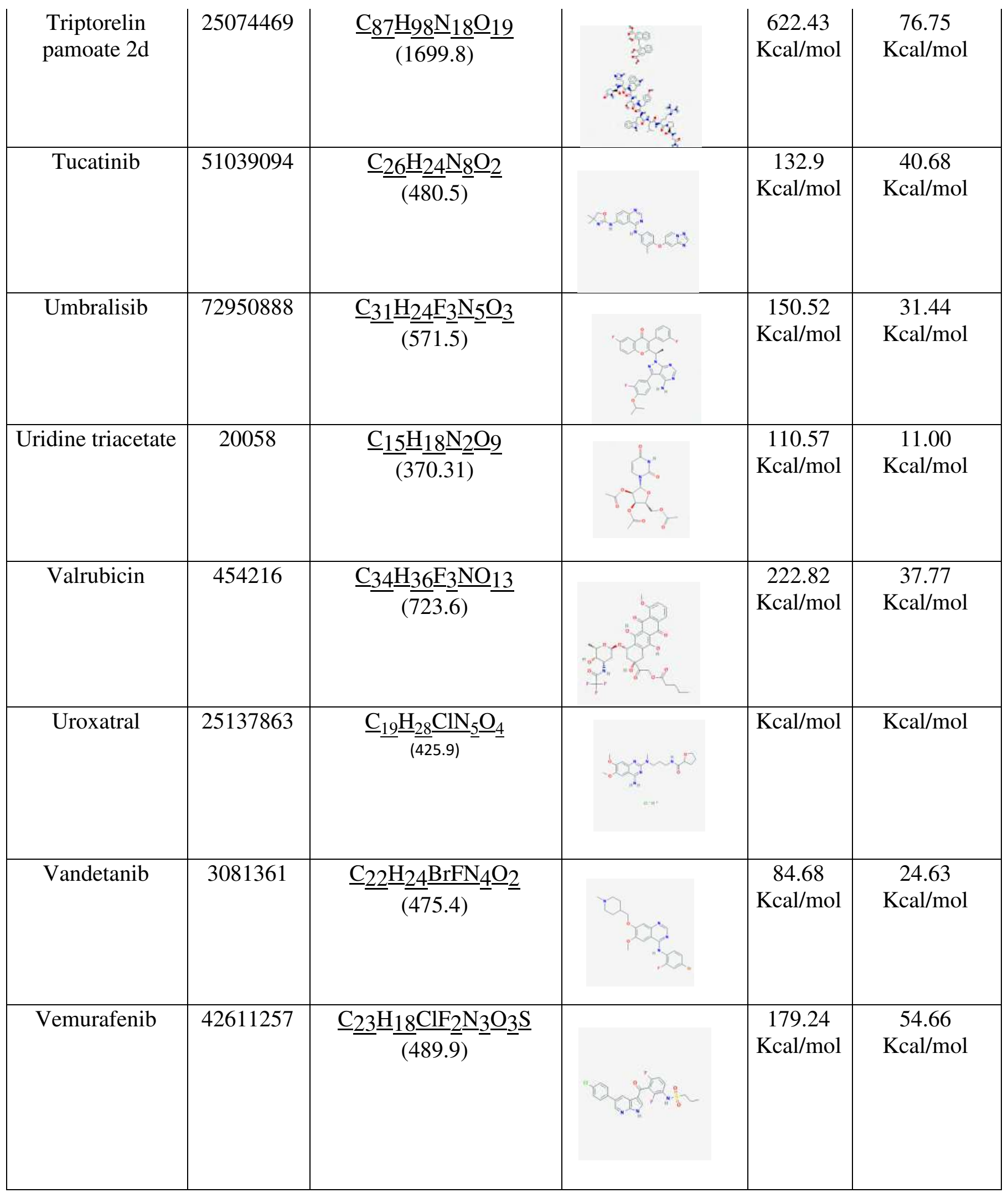




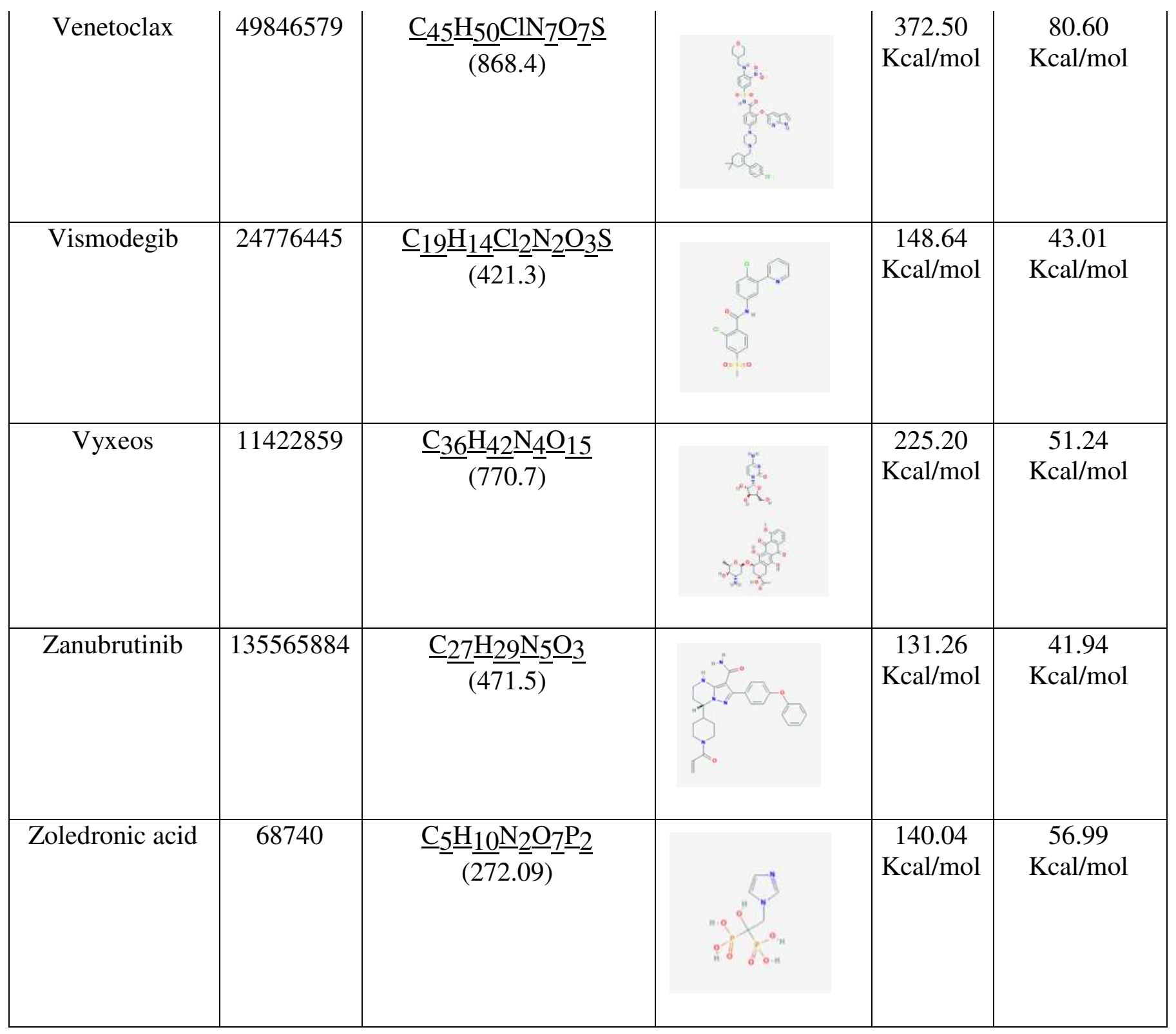


Table 2MolDock score, rerank score, interaction, torsions and hbond energy of the docked compounds with NOS2 protein.

\begin{tabular}{|c|c|c|c|c|c|}
\hline $\begin{array}{c}\text { Name of the } \\
\text { inhibitor }\end{array}$ & $\begin{array}{c}\text { MolDock } \\
\text { Score } \\
\text { Kcal/mol }\end{array}$ & $\begin{array}{c}\text { Rerank } \\
\text { Score } \\
\text { Kcal/mol }\end{array}$ & $\begin{array}{c}\text { Interaction } \\
\text { energy } \\
\text { Kcal/mol }\end{array}$ & $\begin{array}{c}\text { Torsion } \\
\text { angle } \\
\text { Kcal/mol }\end{array}$ & $\begin{array}{c}\text { HBond } \\
\text { Kcal/mol }\end{array}$ \\
\hline
\end{tabular}




\begin{tabular}{|c|c|c|c|c|c|}
\hline Abarelix & -157.81 & -0.93 & -88.92 & 38 & -2.82 \\
\hline Abemaciclib & -110.70 & -79.76 & -114.47 & 7 & -1.06 \\
\hline $\begin{array}{c}\text { Abiraterone } \\
\text { acetate }\end{array}$ & -88.80 & -68.04 & -95.37 & 3 & -1.60 \\
\hline Acalabrutinib & -113.68 & -77.93 & -104.46 & 6 & -2.20 \\
\hline Afatinib & -115.59 & -82.64 & -119.65 & 8 & -4.12 \\
\hline $\begin{array}{c}\text { Afatinib } \\
\text { dimaleate }\end{array}$ & -113.95 & -18.00 & -100.96 & 8 & -2.58 \\
\hline Alectinib & -112.83 & --83.57 & -119.19 & 4 & -0.85 \\
\hline Alimta & -124.39 & -81.05 & -119.96 & 9 & -5.10 \\
\hline Alpelisib & -99.15 & -79.74 & -102.08 & 6 & -3.75 \\
\hline
\end{tabular}




\begin{tabular}{|c|c|c|c|c|c|}
\hline Amifostine & -60.77 & -41.28 & $-58-29$ & 7 & -1.48 \\
\hline Anagrelide & -77.11 & -59.47 & -78.49 & 0 & 0 \\
\hline Anastrozole & -82.61 & -44.79 & -86.85 & 6 & -5.05 \\
\hline $\begin{array}{l}\text { Andrographo } \\
\text { lide }\end{array}$ & -75.25 & -58.00 & -77.85 & 4 & -8.86 \\
\hline Anexsia & -59.88 & -48.51 & -62.40 & 1 & -2.80 \\
\hline Apalutamide & -98.34 & -70.24 & -88.52 & 5 & -1.46 \\
\hline Aprepitant & -117.15 & -74.06 & -114.18 & 8 & 0 \\
\hline Aredia & -52.58 & -39.92 & -54.66 & 4 & -4.20 \\
\hline Arzerra & -89.34 & -71.87 & -88.85 & 1 & -2.5 \\
\hline
\end{tabular}




\begin{tabular}{|c|c|c|c|c|c|}
\hline & -107.75 & -76.35 & -104.53 & 5 & -0.18 \\
\hline Belinostat & -95.39 & -62.95 & -76.57 & 5 & -0.45 \\
\hline $\begin{array}{c}\text { Bendamustin } \\
\text { e }\end{array}$ & -101.90 & -59.29 & -99.32 & 9 & -2.6 \\
\hline Besponsa & -167.05 & -59.76 & -97.25 & 13 & -1.91 \\
\hline Benimetinib & -81.37 & -45.09 & -103.65 & & \\
\hline
\end{tabular}




\begin{tabular}{|c|c|c|c|c|c|}
\hline Bortezomib & -97.34 & -64.69 & -97.64 & 9 & -5.43 \\
\hline Bosutinib & -116.04 & -58.63 & -88.59 & 10 & -1.47 \\
\hline Brigatinib & -78.77 & -40.92 & -96.56 & 8 & -1.87 \\
\hline Bromfenac & -82.54 & -67.10 & -85.77 & 4 & -0.09 \\
\hline Cabazitaxel & -130.75 & -66.02 & -104.44 & 16 & -1.38 \\
\hline Cabozantinib & -107.09 & -86.89 & -124.84 & 8 & - \\
\hline Capecitabine & -91.76 & 20.55 & -99.02 & 7 & -6.55 \\
\hline Carfilzomib & -118.56 & -58.62 & -107.65 & 20 & -3.05 \\
\hline Carmustine & -65.14 & -51.94 & -65.12 & 5 & -2.96 \\
\hline
\end{tabular}




\begin{tabular}{|c|c|c|c|c|c|}
\hline Cedazuridine & -68.87 & -60.84 & -81.77 & 2 & -7.41 \\
\hline Cisplatin & -21.76 & -25.30 & -21.76 & 0 & -4.8 \\
\hline Cinacalcet & -91.56 & -64.25 & -87.26 & 7 & 0 \\
\hline Clofarabine & -86.66 & -68.85 & -86.68 & 2 & -6.11 \\
\hline Cobimetinib & -114.111 & -88.24 & -117.28 & 4 & -2.62 \\
\hline Copanlisib & -110.56 & -51.89 & -109.47 & 8 & -0.23 \\
\hline Copiktra & -84.23 & 4.34 & -88.58 & 4 & -0.85 \\
\hline Crizotinib & -108.28 & -78.07 & -106.19 & 5 & -0.03 \\
\hline Dabrafenib & -101.94 & -60.11 & -78.09 & 6 & 0 \\
\hline
\end{tabular}




\begin{tabular}{|c|c|c|c|c|c|}
\hline Dacomitinib & -87.37 & -63.81 & -96.69 & 8 & -0.35 \\
\hline Darolutamide & -131.34 & -83.17 & -116.02 & 7 & -5.67 \\
\hline Dasatinib & -111.44 & -37.08 & -110.99 & 6 & -3.71 \\
\hline Decitabine & -80.81 & -55.99 & -84.11 & 2 & -6.55 \\
\hline Degarelix & -226.10 & -106.48 & -226.47 & 42 & -10.57 \\
\hline Docetaxel & -125.02 & -72.22 & -114.53 & 14 & -4.38 \\
\hline Doxorubicin & -41.22 & -48.19 & -102.29 & 5 & -8.92 \\
\hline $\begin{array}{c}\text { Elliotts } \\
\text { Region } 10\end{array}$ & -36.43 & -30.21 & -36.43 & 0 & -5.63 \\
\hline $\begin{array}{c}\text { Elliotts } \\
\text { Region } 20\end{array}$ & -45.60 & -43.73 & -64.28 & 1 & -9.11 \\
\hline
\end{tabular}




\begin{tabular}{|c|c|c|c|c|c|}
\hline Elliotts \\
Region 5 & -23.25 & -20.59 & -23.25 & 0 & -3.05 \\
\hline $\begin{array}{c}\text { Eloxatin } \\
\text { Region }\end{array}$ & -35.65 & -33.73 & -46.47 & 0 & -2.24 \\
\hline $\begin{array}{c}\text { Eloxatinregio } \\
\text { n 1 }\end{array}$ & -39.77 & -35.02 & -43.60 & 1 & -5.00 \\
\hline
\end{tabular}




\begin{tabular}{|c|c|c|c|c|c|}
\hline Enasidenib & -65.55 & -62.06 & -97.55 & 8 & -0.04 \\
\hline Encorafenib & -137.86 & -85.89 & -111.07 & 10 & -0.72 \\
\hline Entrectinib & -121.73 & -65.00 & -96.89 & 7 & -0.53 \\
\hline Enzalutamide & -92.14 & -53.70 & -88.76 & 5 & -2.5 \\
\hline Epirubicin & -48.75 & -50.50 & -90.22 & 5 & -7.23 \\
\hline Erdafitinib & -107.92 & -74.48 & -102.36 & 9 & -7.50 \\
\hline Erlotinib & -124.80 & -88.19 & -126.94 & 11 & -0.97 \\
\hline Everolimus & -111.73 & -75.61 & -110.00 & 9 & -6.11 \\
\hline Exemestane & -93.36 & -69.43 & -94.16 & 0 & -1.63 \\
\hline
\end{tabular}




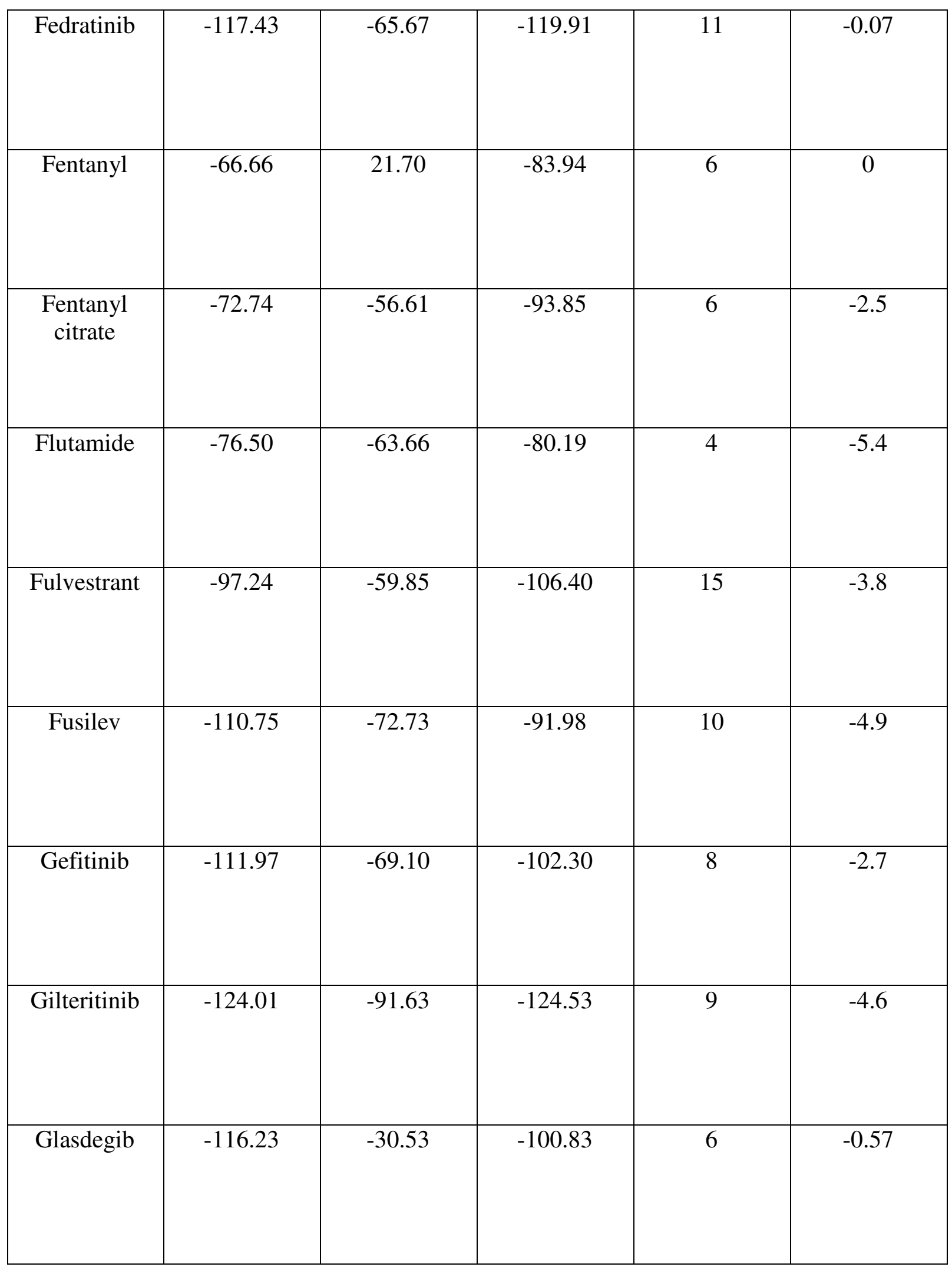




\begin{tabular}{|c|c|c|c|c|c|}
\hline Goserelin & -189.77 & -92.09 & -133.3 & 34 & -7.7 \\
\hline Granisetron & -80.37 & -55.51 & -83.82 & 2 & 0 \\
\hline Ibritumomab & -114.25 & -59.08 & -92.89 & 21 & -3.9 \\
\hline Ibrutinib & -107.41 & -72.47 & -106.97 & 5 & -2.0 \\
\hline Idelalisib & -103.54 & -75.62 & -103.18 & 5 & -0.4 \\
\hline Imatinib & -106.68 & -34.06 & -120.29 & 7 & -2.5 \\
\hline $\begin{array}{l}\text { Ingenol } \\
\text { mebutate }\end{array}$ & -87.17 & -50.38 & -89.31 & 5 & -6.7 \\
\hline $\begin{array}{l}\text { Interferon } \\
\text { alfa-2B }\end{array}$ & -108.07 & -68.29 & -92.12 & 8 & 0 \\
\hline Iodixanol & -144.14 & -74.14 & -94.80 & 22 & -4.0 \\
\hline
\end{tabular}




\begin{tabular}{|c|c|c|c|c|c|}
\hline Irinotecan & -112.18 & -75.20 & -124.62 & 5 & -3.9 \\
\hline Ivosidenib & -156.93 & -73.68 & -119.95 & 8 & -0.3 \\
\hline Ixabepilone & -110.69 & -64.43 & -79.83 & 3 & -3.6 \\
\hline Ixazomib & -95.99 & -67.60 & -88.00 & 7 & -4.5 \\
\hline Lapatinib & -120.46 & -43.73 & -92.37 & 11 & -3.9 \\
\hline Larotrectinib & -134.84 & -76.76 & -95.18 & 5 & 0 \\
\hline $\begin{array}{c}\text { Lenalidomid } \\
\mathrm{e}\end{array}$ & -77.62 & -64.36 & -87.35 & 1 & -0.6 \\
\hline Lenvatinib & -108.85 & -68.09 & -100.74 & 8 & -2.0 \\
\hline Letrozole & -90.19 & -70.54 & -94.06 & 5 & 0 \\
\hline
\end{tabular}




\begin{tabular}{|c|c|c|c|c|c|}
\hline $\begin{array}{l}\text { Leuprolide } \\
\text { acetate }\end{array}$ & -154.10 & -54.06 & -83.42 & 32 & -7.3 \\
\hline Leuprorelin & -164.38 & -62.48 & -123.52 & 32 & -6.0 \\
\hline $\begin{array}{l}\text { Levoleucovo } \\
\text { rin }\end{array}$ & -115.66 & -71.22 & -94.11 & 10 & -5.15 \\
\hline Lonsurf & -73.91 & -64.55 & -83.91 & 3 & -5.35 \\
\hline Lorlatinib & -117.89 & -76.58 & -100.39 & 1 & -1.73 \\
\hline Marqibo & -128.23 & -61.32 & -96.05 & 11 & -0.56 \\
\hline $\begin{array}{l}\text { Mechloretha } \\
\text { mine }\end{array}$ & -45.91 & -35.92 & -47.06 & 4 & 0 \\
\hline $\begin{array}{l}\text { Melphalan } \\
\text { flufenamide }\end{array}$ & -117.04 & -67.83 & -103.58 & 14 & -0.62 \\
\hline Methoxsalen & -78.31 & -47.00 & -80.89 & 1 & -1.79 \\
\hline
\end{tabular}




\begin{tabular}{|c|c|c|c|c|c|}
\hline Midostaurin & -142.42 & -91.15 & -117.86 & 3 & -0.47 \\
\hline Miraluma & -42.80 & -38.82 & -47.08 & 3 & -3.16 \\
\hline $\begin{array}{l}\text { Morphine } \\
\text { sulfate }\end{array}$ & -80.13 & -49.42 & -86.61 & 0 & -5.18 \\
\hline Nelarabine & -85.12 & -66.53 & -89.28 & 3 & -6.47 \\
\hline Neratinib & -103.98 & -77.61 & -113.81 & 12 & -0.64 \\
\hline $\begin{array}{c}\text { Neratinib } \\
\text { maleate }\end{array}$ & -117.95 & -90.09 & -117.32 & 12 & -2.00 \\
\hline Netupitant & -109.24 & -68.92 & -112.85 & 7 & -2.46 \\
\hline Nilotinib & -125.02 & -82.46 & -124.81 & 7 & -2.50 \\
\hline Niraparib & -76.81 & -64.25 & -87.52 & 3 & -2.38 \\
\hline
\end{tabular}




\begin{tabular}{|c|c|c|c|c|c|}
\hline Olaparib & -76.45 & -58.21 & -91.69 & 4 & -1.24 \\
\hline $\begin{array}{l}\text { Omacetaxine } \\
\text { mepesuccinat } \\
\mathrm{e}\end{array}$ & -101.87 & -47.71 & -85.96 & 11 & -4.18 \\
\hline Ondansetron & -88.11 & -62.67 & -86.36 & 2 & -1.80 \\
\hline Osimertinib & -80.97 & -66.57 & -83.53 & 10 & -3.91 \\
\hline Oxaliplatin & -46.54 & -40.41 & -52.19 & 0 & -1.83 \\
\hline Paclitaxel & -132.68 & -60.71 & -108.71 & 14 & -0.94 \\
\hline Palbociclib & -101.88 & -72.68 & -96.65 & 4 & -3.87 \\
\hline Palonosetron & -70.65 & -63.12 & -92.20 & 1 & 0 \\
\hline Panobinostat & -102.40 & -68.77 & -98.26 & 7 & -5.15 \\
\hline
\end{tabular}




\begin{tabular}{|c|c|c|c|c|c|}
\hline $\begin{array}{l}\text { Panobinostat } \\
\text { lactate }\end{array}$ & -127.42 & -56.35 & -125.90 & 7 & -2.11 \\
\hline Pazopanib & -128.95 & -95.28 & -115.36 & 5 & -2.5 \\
\hline $\begin{array}{l}\text { Pefloxacin } \\
\text { mesylate }\end{array}$ & -91.76 & -75.39 & -97.96 & 3 & -2.14 \\
\hline $\begin{array}{c}\text { Pexidartinib } \\
\text { hydrochlorid } \\
\text { e }\end{array}$ & -114.10 & -73.64 & -108.80 & 6 & 0 \\
\hline Pirfenidone & -51.70 & -35.69 & -70.22 & 1 & -0.29 \\
\hline Plerixafor & -128.58 & -83.06 & -108.01 & 4 & -0.72 \\
\hline $\begin{array}{c}\text { Pomalidomid } \\
\mathrm{e}\end{array}$ & -84.84 & -70.11 & -91.58 & 1 & -2.50 \\
\hline Ponatinib & -133.52 & -99.85 & -136.60 & 8 & -2.79 \\
\hline $\begin{array}{c}\text { Ponatinib } \\
\text { hydrochlorid } \\
\mathrm{e}\end{array}$ & -113.27 & -89.39 & -123.75 & 8 & -0.07 \\
\hline
\end{tabular}




\begin{tabular}{|c|c|c|c|c|c|}
\hline $\begin{array}{c}\text { Porfimer } \\
\text { sodium }\end{array}$ & -138.19 & -84.70 & $\begin{array}{l}-104.66 \\
\end{array}$ & 8 & -4.07 \\
\hline Pralatrexate & -125.24 & -70.01 & -103.10 & 11 & -2.34 \\
\hline Pralsetinib & -129.3 & -77.32 & -94.91 & 8 & 0 \\
\hline Premarin & -94.11 & -53.64 & -95.13 & 2 & -1.79 \\
\hline Pregabalin & -62.75 & -48.37 & -61.69 & 5 & -3.0 \\
\hline Quadramet & -83.41 & -56.73 & -82.60 & 11 & -1.53 \\
\hline Raloxifene & -136.16 & -86.90 & -107.13 & 7 & -1.68 \\
\hline Regorafenib & -126.41 & -87.24 & -114.04 & 8 & -3.33 \\
\hline Rolapitant & -114.82 & -74.44 & -116.35 & 7 & 0 \\
\hline
\end{tabular}




\begin{tabular}{|c|c|c|c|c|c|}
\hline Romidepsin & -114.11 & -70.00 & -96.65 & 3 & -0.93 \\
\hline Rucaparib & -94.88 & -71.76 & -96.57 & 3 & 0 \\
\hline Sancuso & -80.33 & -55.64 & -83.72 & 2 & 0 \\
\hline Sorafenib & -119.79 & -81.70 & -102.21 & 8 & -5.1 \\
\hline Sordinol & -107.71 & -21.19 & -94.20 & 6 & 0 \\
\hline Sunitinib & -124.80 & -83.98 & -103.60 & 8 & -0.8 \\
\hline Talazoparib & -116.04 & -80.38 & -110.84 & 2 & -2.0 \\
\hline Tamoxifen & -106.25 & -80.40 & -99.08 & 9 & 0 \\
\hline $\begin{array}{l}\text { Telotristat } \\
\text { ethyl }\end{array}$ & -122.38 & -37.67 & -91.80 & 11 & -3.7 \\
\hline
\end{tabular}




\begin{tabular}{|c|c|c|c|c|c|}
\hline $\begin{array}{c}\text { Temozolomi } \\
\text { de }\end{array}$ & -70.12 & -61.23 & -73.40 & 1 & -3.2 \\
\hline $\begin{array}{c}\text { Temsirolimu } \\
\mathrm{s}\end{array}$ & -100.64 & -71.73 & -109.37 & 11 & -4.2 \\
\hline Tepotinib & -100.97 & -29.96 & -109.74 & 8 & -1.6 \\
\hline Tivozanib & -132.09 & -83.29 & -100.45 & 8 & -1.0 \\
\hline Trametinib & -96.02 & -19.80 & -105.67 & 5 & -4.54 \\
\hline $\begin{array}{l}\text { Trilaciclib } \\
\text { dihydrochlori } \\
\text { de }\end{array}$ & -133.21 & -83.41 & -130.22 & 3 & -0.20 \\
\hline $\begin{array}{l}\text { Triptorelin } \\
\text { pamoate }\end{array}$ & -185.73 & -59.99 & -129.30 & 33 & -2.72 \\
\hline Tucatinib & -121.69 & -66.33 & -96.52 & 5 & -2.40 \\
\hline Umbralisib & -147.49 & -87.26 & -106.60 & 6 & -0.68 \\
\hline
\end{tabular}




\begin{tabular}{|c|c|c|c|c|c|}
\hline $\begin{array}{l}\text { Uridine } \\
\text { triacetate }\end{array}$ & -116.59 & -87.17 & -115.36 & 8 & -5.08 \\
\hline Uroxatral & --117.41 & -55.64 & -111.05 & 8 & -1.13 \\
\hline Valrubicin & --115.98 & -61.15 & -115.51 & 12 & -5.78 \\
\hline Vandetanib & -102.72 & -77.22 & -112.77 & 6 & -3.16 \\
\hline Vemurafenib & -124.80 & -69.76 & -94.51 & 7 & -0.31 \\
\hline Venetoclax & -168.21 & -64.67 & -109.12 & 12 & -0.54 \\
\hline Vismodegib & -97.78 & -73.73 & -97.91 & 4 & -1.51 \\
\hline Vyxeos & -73.33 & -59.61 & -78.45 & 2 & -3.41 \\
\hline Zanubrutinib & -101.69 & -74.84 & -100.71 & 6 & -0.81 \\
\hline
\end{tabular}




\begin{tabular}{|c|c|c|c|c|c|}
\hline $\begin{array}{c}\text { Zoledronic } \\
\text { acid }\end{array}$ & -62.61 & -22.65 & -63.54 & 4 & -3.33 \\
& & & & & \\
\hline
\end{tabular}


Table 3Amino acid residues around active site and docked against NOS2 protein

\begin{tabular}{|c|c|c|}
\hline $\begin{array}{l}\text { Name of } \\
\text { the } \\
\text { Inhibitor }\end{array}$ & Amino acid residues around active site & $\begin{array}{c}\text { Ligand binding amino } \\
\text { acids }\end{array}$ \\
\hline Degarelix & $\begin{array}{c}\text { Glu394C,Glu393C,Asn390C,Val386C,Glu387C,Glu91D, } \\
\text { Pro474D, } \\
\text { Ser92D,His477D,Glu441D,Lys445D,Ile204D,Asn449D, } \\
\text { Glu448D, } \\
\text { Met444D,Met94D,Asn89D,Lys88D,Thr95D,Arg86D }\end{array}$ & $\begin{array}{l}\text { Asn449D,Met94D, } \\
\text { Ser92D, } \\
\text { Pro474D,Val386C,Asn } \\
\text { 89D }\end{array}$ \\
\hline Gosarelin & $\begin{array}{l}\text { Val386C,Glu387C,Gly91D,Glu93D,Ser92D,Asu89D, } \\
\text { Met94D,Phe96D,Glu448D,Met447D,Lys445D, } \\
\text { Met444D,Glu478D,Pro474D,Gly441D }\end{array}$ & $\begin{array}{l}\text { Glu441D,Gly91D, } \\
\text { Met444D,Ser92D }\end{array}$ \\
\hline $\begin{array}{l}\text { Triptorelin } \\
\text { Pamoate }\end{array}$ & $\begin{array}{c}\text { Pro474D,Val386C,Glu441D,Lys445D,Met444D, } \\
\text { Arg452D,Asn449D,Glu448D,Phe96D } \\
\text { Met94D,Gly478D,Asn89D,Ser92D }\end{array}$ & $\begin{array}{c}\text { Glu448D,Met444D, } \\
\text { Ser92D }\end{array}$ \\
\hline $\begin{array}{l}\text { Venetocla } \\
\mathrm{x}\end{array}$ & $\begin{array}{l}\text { Gly93D,Met94D,Asn89D,Ser92D,Glu448D, } \\
\text { Lys445D,Met444D,Pro474D,Glu441D }\end{array}$ & Ser92D,Glu448D \\
\hline
\end{tabular}


Table 4Pharmacophore kinetic and drug-likeness and ADMET properties of top selected ligands

\begin{tabular}{|c|c|c|c|c|c|c|}
\hline Property & Model Name & $\begin{array}{c}\text { Degarel } \\
\text { ix }\end{array}$ & $\begin{array}{c}\text { Gosereli } \\
\text { n }\end{array}$ & $\begin{array}{c}\text { Triptorelin } \\
\text { pamoate }\end{array}$ & Venetoclax & Unit \\
\hline \multirow{4}{*}{$\begin{array}{l}\text { Absorptio } \\
\text { n }\end{array}$} & Water solubility & -2.89 & -2.89 & -2.89 & -3.03 & $\log \mathrm{mol} / \mathrm{L}$ \\
\hline & $\begin{array}{l}\text { Caco2 } \\
\text { permeability }\end{array}$ & 0.622 & -1.50 & -2.58 & 0.84 & $\begin{array}{l}\text { log Papp in } \\
10-6 \mathrm{~cm} / \mathrm{s}\end{array}$ \\
\hline & $\begin{array}{l}\text { Intestinal } \\
\text { absorption(Hum } \\
\text { an) }\end{array}$ & 0 & 0 & 0 & 100 & $\%$ Absorbed \\
\hline & $\begin{array}{l}\text { Skin } \\
\text { Permeability }\end{array}$ & -2.73 & -2.73 & -2.73 & -2.73 & $\log \mathrm{Kp}$ \\
\hline \multirow{4}{*}{$\begin{array}{l}\text { Distributi } \\
\text { on }\end{array}$} & VDss(Human) & -0.536 & -0.24 & -0.012 & 0.329 & $\log 1 / \mathrm{kg}$ \\
\hline & $\begin{array}{l}\text { Fraction } \\
\text { unbound(Human } \\
\text { ) }\end{array}$ & 0.276 & 0.36 & 0.379 & 0.169 & $\mathrm{Fu}$ \\
\hline & $\begin{array}{l}\text { BBB } \\
\text { permeability }\end{array}$ & -2.726 & -3.43 & -4.13 & -1.74 & $\log \mathrm{BB}$ \\
\hline & $\begin{array}{l}\text { CNS } \\
\text { permeability }\end{array}$ & -6.852 & -7.31 & -7.49 & -3.11 & $\log \mathrm{PS}$ \\
\hline \multirow[t]{7}{*}{$\begin{array}{l}\text { Metabolis } \\
\mathrm{m}\end{array}$} & $\begin{array}{l}\text { CYP2D6 } \\
\text { substrate }\end{array}$ & No & No & No & No & \multirow{7}{*}{ Yes/No } \\
\hline & $\begin{array}{l}\text { CYP3A4 } \\
\text { substrate }\end{array}$ & Yes & Yes & No & Yes & \\
\hline & $\begin{array}{l}\text { CYP1A2 } \\
\text { inhibitor }\end{array}$ & No & No & No & No & \\
\hline & $\begin{array}{l}\text { CYP2C19 } \\
\text { inhibitor }\end{array}$ & No & No & No & No & \\
\hline & $\begin{array}{l}\text { CYP2C9 } \\
\text { inhibitor }\end{array}$ & No & No & No & No & \\
\hline & $\begin{array}{l}\text { CYP2D6 } \\
\text { inhibitor }\end{array}$ & No & No & No & $\mathrm{NO}$ & \\
\hline & $\begin{array}{l}\text { CYP3A4 } \\
\text { inhibitor }\end{array}$ & No & No & No & Yes & \\
\hline \multirow[t]{2}{*}{ Excretion } & Total clearance & -0.897 & 0.414 & -1.04 & -0.09 & $\begin{array}{l}\log \\
\mathrm{ml} / \mathrm{min} / \mathrm{kg}\end{array}$ \\
\hline & $\begin{array}{l}\text { Renal OCT2 } \\
\text { substrate }\end{array}$ & No & No & No & No & \multirow[t]{2}{*}{ Yes/No } \\
\hline \multirow[t]{4}{*}{ Toxicity } & AMES toxicity & No & No & Yes & No & \\
\hline & $\begin{array}{l}\text { Max. tolerated } \\
\text { dose(Human) } \\
\end{array}$ & 0.438 & 0.438 & 0.438 & 0.278 & $\begin{array}{l}\log \\
\mathrm{mg} / \mathrm{kg} / \text { day }\end{array}$ \\
\hline & hERG I inhibitor & No & No & No & No & Yes/No \\
\hline & $\begin{array}{l}\text { Oral rat acute } \\
\text { toxicity(LD50) } \\
\end{array}$ & 2.482 & 2.482 & 2.482 & 2.60 & $\mathrm{Mol} / \mathrm{kg}$ \\
\hline
\end{tabular}




\begin{tabular}{|c|c|c|c|c|c|c|}
\hline & $\begin{array}{l}\text { Oral rat chronic } \\
\text { toxicity(LOAEL } \\
\text { ) }\end{array}$ & 10.202 & 7.479 & 10.343 & 1.924 & $\begin{array}{l}\log \\
\mathrm{mg} / \mathrm{kg} \text { _bw/ } \\
\text { day }\end{array}$ \\
\hline & Hepatotoxicity & Yes & Yes & No & Yes & \multirow[b]{2}{*}{ Yes/No } \\
\hline & $\begin{array}{l}\text { Skin } \\
\text { sensitization }\end{array}$ & No & No & No & No & \\
\hline & $\begin{array}{l}\text { T.pyriformis } \\
\text { toxicity }\end{array}$ & 0.285 & 0.285 & 0.285 & 0.285 & $\log \mu \mathrm{g} / \mathrm{L}$ \\
\hline & Minnow toxicity & 6.928 & 10.099 & 7.236 & -0.48 & $\log \mu \mathrm{g} / \mathrm{L}$ \\
\hline $\begin{array}{l}\text { Drug } \\
\text { likeness }\end{array}$ & Lipinski & No & No & No & No & Yes/No \\
\hline \multirow{6}{*}{$\begin{array}{l}\text { Bioactivit } \\
\text { y Score }\end{array}$} & GPCR ligand & -4.01 & -3.84 & -3.87 & -2.36 & \\
\hline & $\begin{array}{l}\text { Ion channel } \\
\text { modulator }\end{array}$ & -4.04 & -3.92 & -3.94 & -3.42 & \\
\hline & Kinase inhibitor & -4.05 & -3.93 & -3.95 & -3.00 & \\
\hline & $\begin{array}{l}\text { Nuclear receptor } \\
\text { ligand }\end{array}$ & -4.08 & -3.98 & -3.99 & -3.33 & \\
\hline & $\begin{array}{l}\text { Protease } \\
\text { inhibitor }\end{array}$ & -3.98 & -3.77 & -3.82 & -1.92 & \\
\hline & $\begin{array}{l}\text { Enzyme } \\
\text { inhibitor }\end{array}$ & -4.03 & -3.88 & -3.91 & -2.87 & \\
\hline
\end{tabular}




\section{References}

1. Arbyn, M.; Weiderpass, E.; Bruni, L.; de Sanjosé, S.; Saraiya, M.; Ferlay, J.; Bray, F. Estimates of incidence and mortality of cervical cancer in 2018: a worldwide analysis. Lancet Glob. Heal. 2020, 8, e191-e203, doi:10.1016/S2214-109X(19)30482-6.

2. Fontham, E.T.H.; Wolf, A.M.D.; Church, T.R.; Etzioni, R.; Flowers, C.R.; Herzig, A.; Guerra, C.E.; Oeffinger, K.C.; Shih, Y.T.; Walter, L.C.; et al. Cervical cancer screening for individuals at average risk: 2020 guideline update from the American Cancer Society. CA. Cancer J. Clin. 2020, 70, 321-346, doi:10.3322/caac.21628.

3. Kaarthigeyan, K. Cervical cancer in India and HPV vaccination. Indian J. Med. Paediatr. Oncol. 2012, 33, 7-12, doi:10.4103/0971-5851.96961.

4. Ambs, S.; Merriam, W.G.; Bennett, W.P.; Felley-Bosco, E.; Ogunfusika, M.O.; Oser, S.M.; Klein, S.; Shields, P.G.; Billiar, T.R.; Harris, C.C. Frequent nitric oxide synthase-2 expression in human colon adenomas: Implication for tumor angiogenesis and colon cancer progression. Cancer Res. 1998, 58, 334-341.

5. Hussain, S.P.; Trivers, G.E.; Hofseth, L.J.; He, P.; Shaikh, I.; Mechanic, L.E.; Doja, S.; Jiang, W.; Subleski, J.; Shorts, L.; et al. Nitric oxide, a mediator of inflammation, suppresses tumorigenesis. Cancer Res. 2004, 64, 6849-6853, doi:10.1158/00085472.CAN-04-2201.

6. Chen, H.H.W.; Su, W.C.; Chou, C.Y.; Guo, H.R.; Ho, S.Y.; Que, J.; Lee, W.Y. Increased expression of nitric oxide synthase and cyclooxygenase-2 is associated with poor survival in cervical cancer treated with radiotherapy. Int. J. Radiat. Oncol. Biol. Phys. 2005, 63, 1093-1100, doi:10.1016/j.ijrobp.2005.03.062.

7. Pasha, A.; Kumbhakar, D.V.; Doneti, R.; Kumar, K.; Dharmapuri, G.; Poleboyina, P.K.; S. K., H.; Basavaraju, P.; Pasumarthi, D.; S. D., A.; et al. Inhibition of Inducible Nitric Oxide Synthase (iNOS) by Andrographolide and in Vitro Evaluation of Its Antiproliferative and Proapoptotic Effects on Cervical Cancer. Oxid. Med. Cell. Longev. 2021, 2021, doi:10.1155/2021/6692628.

8. RCSB PDB: Homepage Available online: https://www.rcsb.org/ (accessed on Jun 24, 2021).

9. PubChem Available online: https://pubchem.ncbi.nlm.nih.gov/ (accessed on Jun 24, 2021).

10. Irwin, J.J.; Sterling, T.; Mysinger, M.M.; Bolstad, E.S.; Coleman, R.G. ZINC: A free tool to discover chemistry for biology. J. Chem. Inf. Model. 2012, 52, 1757-1768.

11. Wishart, D.S.; Feunang, Y.D.; Guo, A.C.; Lo, E.J.; Marcu, A.; Grant, J.R.; Sajed, T.; Johnson, D.; Li, C.; Sayeeda, Z.; et al. DrugBank 5.0: A major update to the DrugBank database for 2018. Nucleic Acids Res. 2018, 46, D1074-D1082, doi:10.1093/nar/gkx1037. 
12. Hyper Available online: https://hyper.com/ (accessed on Jun 24, 2021).

13. ChemDraw - PerkinElmer Available online:

https://perkinelmerinformatics.com/products/research/chemdraw/ (accessed on Jun 24, 2021).

14. Bitencourt-Ferreira, G.; de Azevedo, W.F. Molegro virtual docker for docking. In Methods in Molecular Biology; Humana Press Inc., 2019; Vol. 2053, pp. 149-167.

15. Molegro Data Modeller | Macs in Chemistry Available online: https://www.macinchem.org/blog/files/671a3395f65b525e75347a60edf7935e-236.php (accessed on Jun 24, 2021).

16. Molegro Molecular Viewer - Molexus Available online: http://molexus.io/molegromolecular-viewer/ (accessed on Jun 24, 2021).

17. Daoud, I.; Melkemi, N.; Salah, T.; Ghalem, S. Combined QSAR, molecular docking and molecular dynamics study on new Acetylcholinesterase and Butyrylcholinesterase inhibitors. 2018, doi:10.1016/j.compbiolchem.2018.03.021.

18. Sadeghi, F.; Afkhami, A.; Madrakian, T.; Ghavami, R. Computational study to select the capable anthracycline derivatives through an overview of drug structure-specificity and cancer cell line-specificity. Chem. Pap. 2021, 75, 523-538, doi:10.1007/s11696-02001321-z.

19. Hocquet, A.; Langgård, M. An evaluation of the MM+ force field. J. Mol. Model. 1998, 4, 94-112, doi:10.1007/s008940050128.

20. Swiss PDB Viewer - Home Available online: https://spdbv.vital-it.ch/ (accessed on Jun 24, 2021).

21. Balakumar, C.; Ramesh, M.; Tham, C.L.; Khathi, S.P.; Kozielski, F.; Srinivasulu, C.; Hampannavar, G.A.; Sayyad, N.; Soliman, M.E.; Karpoormath, R. Ligand- and structurebased in silico studies to identify kinesin spindle protein (KSP) inhibitors as potential anticancer agents. J. Biomol. Struct. Dyn. 2018, 36, 3687-3704, doi:10.1080/07391102.2017.1396255.

22. Prasad, C.; Rao, A.V.; Rao, M.V. Computer aided design and molecular docking studies on a series of 1,3-thiazolidine-2, 4-diones as new class of 5-lipoxygenase inhibitors. 2014, 8, 858-863.

23. Kaushik, P.; Lal Khokra, S.; Rana, A.C.; Kaushik, D. Pharmacophore modeling and molecular docking studies on pinus roxburghii as a target for diabetes mellitus. $A d v$. Bioinformatics 2014, 2014, doi:10.1155/2014/903246.

24. Yang, J.M.; Chen, C.C. GEMDOCK: A Generic Evolutionary Method for Molecular Docking. Proteins Struct. Funct. Genet. 2004, 55, 288-304, doi:10.1002/prot.20035.

25. Wolber, G.; Langer, T. LigandScout: 3-D pharmacophores derived from protein-bound ligands and their use as virtual screening filters. J. Chem. Inf. Model. 2005, 45, 160-169, 
doi:10.1021/ci049885e.

26. Rella, M.; Rushworth, C.A.; Guy, J.L.; Turner, A.J.; Langer, T.; Jackson, R.M. Structurebased pharmacophore design and virtual screening for novel Angiotensin Converting Enzyme 2 inhibitors. J. Chem. Inf. Model. 2006, 46, 708-716, doi:10.1021/ci0503614.

27. Alhazmi, M.I. Hypothesis Volume 11(4) Molecular docking of selected phytocompounds with H1N1 Proteins. Bioinformation 2015, 11, 196.

28. Thangavelu, R.; Faisal, S. Prediction of molecular properties, bioactivity \& docking of novel hydrazines. Int. J. Trends Pharm. Life Sci. 2016, 2, 757-768.

29. Yadav, A.R.; Mohite, S.K. Anticancer Activity and In-Silico ADMET Analysis of Malvastrum Coromandelianum;

30. Pires, D.E. V; Blundell, T.L.; Ascher, D.B.; 1ga, U.K. pkCSM: Predicting SmallMolecule Pharmacokinetic and Toxicity Properties Using Graph-Based Signatures. 2015, doi:10.1021/acs.jmedchem.5b00104.

31. Laskowski, R.A.; Jabło nska, J.; Pravda, L.; Svobodov Va rekov, R.; Thornton, J.M. TOOLS FOR PROTEIN SCIENCE PDBsum: Structural summaries of PDB entries. 2017, doi:10.1002/pro.3289.

32. Laskowski, R.A.; MacArthur, M.W.; Moss, D.S.; Thornton, J.M. PROCHECK: a program to check the stereochemical quality of protein structures. J. Appl. Crystallogr. 1993, 26, 283-291, doi:10.1107/s0021889892009944.

33. Colovos, C.; Yeates, T.O. Verification of protein structures: Patterns of nonbonded atomic interactions. Protein Sci. 1993, 2, 1511-1519, doi:10.1002/pro.5560020916.

34. SAVESv6.0 - Structure Validation Server Available online: https://saves.mbi.ucla.edu/ (accessed on Jun 25, 2021).

35. Copeland, R.A. Conformational adaptation in drug-target interactions and residence time. Future Med. Chem. 2011, 3, 1491-1501.

36. Guan, L.; Yang, H.; Cai, Y.; Sun, L.; Di, P.; Li, W.; Liu, G.; Tang, Y. ADMET-score-a comprehensive scoring function for evaluation of chemical drug-likeness. Medchemcomm 2019, 10, 148-157, doi:10.1039/C8MD00472B.

37. Galea, E.; Feinstein, D.L. Regulation of the expression of the inflammatory nitric oxide synthase ( NOS2 ) by cyclic AMP. 2018, 2125-2137.

38. Sharma, V.; Sharma, P.C.; Kumar, V. In Silico Molecular Docking Analysis of Natural Pyridoacridines as Anticancer Agents. 2016, 2016.

39. Shore, N.D. Experience with degarelix in the treatment of prostate cancer. Ther. Adv. Urol. 2013, 5, 11-24, doi:10.1177/1756287212461048.

40. Jonat, W. Goserelin ( Zoladex ${ }^{\mathrm{TM}}$ ) - its role in early breast cancer in pre- and perimenopausal women. 2001, 85, 1-5. 
41. Matched, A.R.; Control, C.; Li, Q.; Zhu, Y.; Sun, J.; Li, F. Role of Goserelin in Combination with Endocrine Therapy for the Treatment of Advanced Breast Cancer in Premenopausal Women Positive for Hormone Receptor : 2013, 28, doi:10.1089/cbr.2012.1436.

42. Aslam N, Nadeem K, Noreen R, J.A.C. Prostate Cancer Prostate Cancer. Abeloff's Clin. Oncol. 5/e 2015, 8, 938-944.

43. Frampton, J.E. Triptorelin: A Review of its Use as an Adjuvant Anticancer Therapy in Early Breast Cancer. Drugs 2017, 77, 2037-2048, doi:10.1007/s40265-017-0849-3.

44. Li, Q.; Cheng, L.; Shen, K.; Jin, H.; Li, H.; Cheng, Y.; Ma, X. Efficacy and safety of BcL2 inhibitor venetoclax in hematological malignancy: A systematic review and metaanalysis of clinical trials. Front. Pharmacol. 2019, 10, 1-12, doi:10.3389/fphar.2019.00697. 